\title{
Öğrencilerin Fiziksel ve Kimyasal Değişme Kavramları İle Bağlamları İlişkilendirme
}

\section{Durumlarının İncelenmesi*}

\author{
Arzu KİRMAN BİLGİN**, Nevzat YİĞİT***
}

Öz: $\mathrm{Bu}$ araştırma, ilişkilendirme (Relating), tecrübe etme (Experiencing), uygulama (Applying), iş birliği (Cooperating) ve transfer etme (Transferring) basamaklarından oluşan REACT stratejisine yönelik geliştirilen öğretim materyallerinin öğrencilerin fiziksel ve kimyasal değişme kavramları ile bağlamları ilişkilendirmeleri üzerine etkisini incelenmeyi amaçlamaktadır. Araştırma deneysel araştırma yönteminin ön test - son test kontrol gruplu deseni ile yürütülmüştür. Deney grubu 50, kontrol grubu 51 olmak üzere 101, 6. sinıf öğrencisi araştırmaya katılmıştır. Geliştirilen öğretim materyali animasyonlardan, çalışma yapraklarından ve örnek olaylardan oluşmaktadır. Öğretim materyali sıcak hava balonu ve çalışma prensibi ana bağlamı çerçevesinde geliştirilmiş ve REACT stratejisinin her basamağında bağlamsal öğrenmeye dikkat edilmiştir. Araştırma verileri, iki aşamalı sorulardan oluşan bağlam testi ve yarı yapılandırılmış mülakat sorularıyla toplanmıştır. Bağlam testinden elde edilen veriler Mann Whitney-U testine, mülakattan elde edilen veriler ise içerik analizine tabi tutulmuştur. Bulgular deney grubunda yürütülen öğretim materyalinin kontrol grubunda yürütülen öğretim materyaline göre daha etkili olduğunu göstermektedir. Araştırma da öğrencilerin meydana gelen değişimleri, karşılaştıkları maddelerin yararlı ve zararlı olmasıyla, birisi tarafından müdahale edilme veya kendiliğinden olma, tekrar geri getirme gibi özelliklerle ilişkilendirmekte ve çoğunlukla da genellemelere gidererek alternatif kavrama oluşturdukları tespit edilmiştir. Bir sonraki araştırmalar için tespit edilen bu genellemeleri içeren öğretim materyallerinin geliştirilmesi ve etkililiğinin incelenmesi önerilebilir.

Anahtar Kavramlar: Fiziksel değişme, Kimyasal değişme, Bağlam, REACT,

İlişkilendirme

\footnotetext{
*"Maddenin Yapısı ve Özellikleri Ünitesi Kapsamında REACT Stratejisine Yönelik Tasarlanan Öğretim Materyallerinin Etkililiğinin Değerlendirilmesi" başlıklı doktora tezinden üretilmiştir.

${ }^{* *}$ Yrd. Doç. Dr. - Kafkas Üniversitesi - Eğitim Fakültesi - Matematik ve Fen Bilimleri Eğitimi Bölümü/KARS arzukirmanbilgin@gmail.com

**** Doç. Dr. - Karadeniz Teknik Üniversitesi - Fatih Eğitim Fakültesi - Matematik ve Fen Bilimleri Eğitimi Bölümü/TRABZON - nevzatyigit@yahoo.com

$\begin{array}{lll}\text { Gönderim:29.12.2016 Kabul:07.03.2017 } & \text { Yayın:03.04.2017 }\end{array}$
}




\section{The Investigation of Students' Responses to Revelation of the Relation between} "Physical and Chemical Change" Concepts and Contexts

Abstract: This study has been carried out within the scope of "physical and chemical change" unit from $6^{\text {th }}$ grade curriculum. A REACT (Relating-Experiencing-ApplyingCooperating-Transferring) strategy has been designed and this study seeks to analyze its effects on students' associating scientific concepts with contexts. This is an experimental study with pre-test post-test control groups. This study has been conducted with total 101 students with 50 students from experimental groups and 51 students from control groups. The developed teaching material consists of animations, worksheets and case studies. The hot air balloon and its working principle are used in the main context of teaching material. Teaching materials are based on REACT strategy, which prioritizes contextual learning in each phase, have been developed. Data collection tools are contextual tests that consist of two-tier questions and interviews. Mann Whitney-U test has been applied to the data obtained from the context test; a content analysis has been applied to the data obtained from interview. The results of data collection tools are indicative of the fact that teaching materials based on REACT strategy are more effective than teachers' teaching materials. This study has shown that students have been associated with the physical and chemical changes through the attributes of useful matter, harmful matter, spontaneity, intervening in change and returning, and they have constructed alternative concepts as they have made generalizations to relate the events. For further research, developing teaching materials containing these generalizations can be recommended, and the effectiveness of these teaching materials using contexts can be tested.

Key Words: Physical change, Chemical change, Context, REACT, Relating 
Giriş

Yaşantılar ile fen kavramları arasındaki ilişkinin en verimli şekilde öğrenciye sunulacağ1 yol bağlamlardır (Gilbert, 2006; Gilbert, Bulte ve Pilot, 2011). Gilbert (2006) bağlamı, bir kavramı uygulama ve kavramın mevcut olay içerisindeki yeri ve önemini ortaya çıkarma olarak tanımlamaktadır. Kullanılacak olan bağlamlar, öğretimle ilgili konu ve kazanımları kapsamakla birlikte kavramların uygulama alanları ve öğrencilerin sosyal ve çalışma kültürünü kapsayan örneklerin seçilmesiyle elde edilir (Morrison, Ross, Kemp ve Kalman, 2010). Tasarlanacak olan öğretimin görevi ise tek başlarına bir anlam ifade etmeyen olay ve nesneleri zengin bir bağlam içerisinde sunmak olmalıdır (Richey, 2000). Öğrencilerin okul dışı ortamlardaki yaşantılarını sınıfta sunulan yeni bilgi ve deneyimlerle yapılandırabilmesi için karşılaştığı yeni durumu önceki bildikleri ile ilişkilendirmesi gerekmektedir (Driver, 1988). Fakat öğrenciler çevresel faktörlerden etkilenerek alternatif kavramalar oluşturmaktadırlar. Bu alternatif kavramalar öğretim sürecini etkiler (Johnson, 1998) ve bazen öğretim sonunda da değişmeden kalabilmektedir (Novak, 1988; Nusbaum ve Novick, 1982). Örneğin; 6. sınıf Fen bilimleri öğretim programında yer alan ve günlük hayatımızda birçok olayı açıklamak için kullandığımız fiziksel-kimyasal değişme konusu öğrencilerin çok sayıda alternatif kavramalara sahip oldukları konulardan bir tanesidir (Adbo ve Taber, 2009; Demircioğlu, Özmen ve Demircioğlu, 2006; Eilks, Moellering ve Valanides, 2007; Tsaparlis, 2003). Öğrenciler suyun buharlaşırken kimyasal bir değişmeye uğradığgnı ve bu değişim sonucunda oksijenin ve hidrojenin açığa çıktığını (Goodwin, 2000; Othman, Treagust ve Chandrasegaran, 2008), yoğunlaşırken ise oksijen ve hidrojenin birleşerek suyu oluşturduğunu düşünmektedirler (Adbo ve Taber, 2009; Bakırc1, Subay, Midyatlı ve Ünsal, 2010). Doğranan meyvelerin kararmasının (Demircioğlu vd., 2006) ve çürüme olaylarının 
fiziksel değişme (Atasoy, Genç, Kadayıfçı ve Akkuş, 2007) olduğunu düşünmektedirler. Bu alternatif kavramalar, öğrencilerin doğayı yanlış yorumlamalarına, bozulan besinleri tüketmelerine ve sağlık problemleriyle karşılaşmalarına neden olabilir. Bu yüzden fiziksel ve kimyasal değişme konusu günlük hayatımızda önemli bir yer tutmaktadır. İlgili konunun kavranması sonraki öğrenmeler için de önemlidir. Fiziksel - kimyasal değişme konusu 7. sınıfta kavranacak olan çözünme, 8. sınıfta ise yanma tepkimeleri, asit-baz tepkimeleri, kütlenin korunumu, fotosentez, oksijenli ve oksijensiz solunum gibi kavramların kavranmas1 için temel oluşturan bir konudur. Örneğin, öğrenciler 7. sınıfta öğrenecekleri çözünme olayının kimyasal bir değişme olduğunu düşünmektedirler (Ahtee ve Varjola, 1998; BouJaoude, 1992; Eilks, Moellering ve Valanides 2007; Novak ve Musonda, 1991; Stavridou \& Solomonidou, 1998; Valanides, 2000). Çözünme kavramı da yine günlük hayatımızda sıkça karşılaştığımız bir olaydır. Öğrenciler her hangi bir değişmeyi fiziksel ve kimyasal olarak sınıflandırırken $\imath S \imath$ - madde oluşumu - gaz çıkışı - tahrip olma - çözünme gibi durumları dikkate almaktadır (Stavridou ve Solomonidou, 1998). Bu özeliklerin ölçüt alınması da öğrencilerin konuyla ilgili alternatif kavramaya sahip olmalarına neden olmaktadır. Ölçüt alınan diğer bir özellik de meydana gelen değişmelerin tersinir olma durumlarıdır. Sökmen, Bayram ve Yılmaz (2000) öğrencilerin tersinir olayları fiziksel değişim, tersinir olmayan olayları ise kimyasal değişim olarak açıkladıklarını tespit etmiş̧tir. Özmen ve Ayas (2003) öğrencilerin konuyla ilgili alternatif kavrama üretmelerinin sebeplerinden bir tanesinin kimyasal değişim olaylarında kütlenin korunumunu kavrayamamalarından kaynaklandığını vurgulamaktadır. Tsaparlis (2003), öğrencilerin fiziksel değişimin doğal yollardan, kimyasal değişimin laboratuvar ortamlarında olduğunu düşündüklerini, Çalık ve Ayas (2005), öğrencilerin bu olayları geri dönüştürülebilir yorumunu kullanarak tanımladıklarını, Eilks, Moellering ve Valanides (2007) ise öğrencilerin 
bir olayın fiziksel veya kimyasal değişim olduğunu söyleyebilseler de nedenlerini açıklayamadıklarını, Coştu, Ayas ve Ünal (2007) gereğinden az veya fazla genelleme yapma eğilimleri alternatif kavramaların oluşmasının başlıca nedenleri arasında geldiğini tespit etmiştir. Demircioğlu vd. (2006) öğretmen adaylarının maddenin yüzeyinde olan her türlü değişimi fiziksel olarak düşündüklerini ortaya çıkarmıştır. Yapılan araştırmaların sonuçları incelendiğinde öğrencilerin eksik bilgi, günlük hayat deneyimleri ve aşırı genelleme yapma eğilimlerinin fiziksel ve kimyasal değişme konusuyla ilgili alternatif kavramalara sebep olduğunu göstermektedir. Fen bilimleri dersini öğretmek için akademik başarıyı olumsuz etkileyen bu alternatif kavramaların göz önünde bulundurulduğu öğrenme ortamlarının tasarlanması gerekmektedir (Driver, 1988).

Fen bilimleri dersinde akademik başarıyı olumsuz etkileyen bir diğer sebep ise öğrencilerin okulda öğrendikleri bilgileri günlük hayatlarında önemli olmadığını düşünmeleridir (Gilbert, 2006). Öğrenciler karşılaştıkları okul dışı deneyimlerinin fen bilimleri derslerinin bir parçası olduğunu keşfettiklerinde daha kolay öğrenmektedirler (Mayoh ve Knutton, 1997). Bağlam temelli öğrenme yaklaşımına göre öğrenme, bir kavram, farklı bir durum içerisindeki farklı bir problemi çözmek için kullanılıyorsa gerçekleşir (Gilbert vd., 2011). Sınıf ortamında fen kavramlarını öğrenemeyen öğrenciler ise yaşantılarında karşılaştıkları problemleri açıklamak için alternatif kavramalara başvurmaktadırlar. Solsona, Izquierdo ve De Jong (2003) öğrenciler günlük hayat durumlarıyla sınıfta ne kadar çok karşılaşırsa öğrenmenin o kadar anlam kazanacağını belirtmektedir. Bir öğretmen ise öğrenme ortamında yeni bilgileri inşa edeceği ön fikirleri görmezlikten gelemez ve öğrenciler arasındaki farklılığg kapatmak için öğretim sürecinde bağlamlar oluşturarak öğrenciler arasında ortak bir payda oluşturur (Whitelegg ve Parry, 1999). REACT (Bkz. Tablo 1) stratejisi de bu amaç doğrultusunda ele alınabilecek verimli 
bir öğretim sürecini kapsamaktadır (Crawford, 2001; Crafword ve Witte, 1999). Çünkü REACT stratejisi öğretimin bağlamlar kapsamında yürütülmesine, kavramlar ile bağlamlar arasındaki ilişkinin ortaya çıkarılmasına, öğrencileri arasındaki iletişimin ön planda tutulmasına ve öğrencilerin öğrendiklerini transfer etmesine olanak sağlar. REACT stratejisi bağlam temelli öğrenme yaklaşımının öğrenme ortamlarına yansıtılan uygulama şekillerinden bir tanesidir. Yapılan araştırmalar gerek akademik başarı (Demircioğlu, Vural ve Demircioğlu, 2012; Ingram, 2003) gerekse kavramsal anlama (Ayvac1, Er Nas ve Dilber, 2016; Er Nas, Şenel Çoruhlu ve Kirman Bilgin, 2016; Ültay, Durukan ve Ültay, 2015) değişkenleri üzerinde REACT stratejisinin olumlu etkileri olduğunu göstermektedir. Fakat REACT stratejisinin kavramlar ile bağlamlar arasındaki ilişkiyi nasıl etkilediğine dair araştırmalara rastlanmamıştır. Oysa bağlam temelli öğrenme yaklaşımı, bilgiye duyulan ihtiyacın hissedilmesi için günlük hayat uygulamalarının fen kavramlarıyla açıklanması gerektiğini vurgulamaktadır (King, Winner ve Ginns, 2011). Öğrencilerin özellikle kimya kavramları ile ilgili bilimsel bilgilerini kullanarak, günlük yaşantısıyla ilişkilendirmesi ve karşılaştığı sorunlara bu bilgileri 1şığında çözüm bulabilmesinin zor bir süreç olduğu (Özmen, 2003) düşünüldügünde, öğrencilerin fiziksel - kimyasal değişme olaylarını günlük hayat deneyimleriyle ne kadar ilişkilendirebildikleri fen öğretimi açısından merak konusudur.

\section{Amaç}

$\mathrm{Bu}$ çalışma; REACT stratejisine yönelik geliştirilen öğretim materyallerinin öğrencilerin fiziksel ve kimyasal değişme kavramları ile bağlamları ilişkilendirmeleri üzerine etkisini incelenmeyi amaçlamaktadır.

\section{Yöntem}

Mevcut araştırma yarı deneysel araştırma yönteminin ön test- son test kontrol gruplu deseni ile yürütülmüştür. 
Örneklem: Araştırmaya Trabzon ili Akçaabat ilçesinde öğrenim gören bir ortaokulun 6. sınıf öğrencileri katılmıştır. 50 deney grubu 51 kontrol grubu olmak toplam 101, öğrenci araştırmanın örneklemini oluşturmaktadır. Mülakatlar bağlam testinin ön test sonuçlarına göre gruplardan üst, orta ve alt seviyede bulunan, rastgele seçilen altı deney grubu altı kontrol grubu olmak üzere toplam on iki öğrenci ile yürütülmüştür.

Tasarlanan Öğretim: Araştırma kapsamında geliştirilen öğrenci rehber materyali REACT stratejisine göre tasarlanmıştır. Araştırmaya konu olan REACT stratejisi (Crawford ve Witte, 1999; Hull, 1999; Crawford, 2001; Navarra, 2006) Tablo 1'deki gibi özetlenmiştir.

Tablo 1. REACT Stratejisinin Tanitılması

\begin{tabular}{|c|c|}
\hline $\begin{array}{l}\text { İlişkilendirme } \\
\text { (Relating) }\end{array}$ & $\begin{array}{l}\text { Öğrenciler kendi deneyimleri ile öğrenecekleri bilgiler arasında direkt olarak ilişki } \\
\text { kurmakta zorlandıklarından dolayı öğretmenlerin bu süreci iyi planlamaları gerekmektedir. } \\
\text { Bu basamakta ders öğretmeni konu ile ilgili kavramlarla gerçek hayat deneyimlerinden } \\
\text { seçilerek sunulan bağlam arasında öğrencilerin ilişki kurmalarına yardımcı olur, derse olan } \\
\text { dikkati ve motivasyonu artırır. Öğrencilerin sunulan bağlam içerisindeki yeni kavramları } \\
\text { seçerek, ön bilgileri ile bütünleştirmesi için İlişkilendirme süreci, bir araç olarak kullanılır. } \\
\text { Kavram ile bağlam arasındaki ilişkinin başarıll bir şekilde kurulması öğrenmenin başarı ile } \\
\text { sonuçlanacağının ilk sinyalidir. Öğretmenler derse her öğrencinin günlük hayatında } \\
\text { karşlaşabileceği duruma örnek verip bu örnekle ilgili soru sorarak başlayabilir. }\end{array}$ \\
\hline & $\begin{array}{l}\text { Bağlamın veya özelliklerinin sınıf ortamına taşınarak öğrencilere bulma, keşfetme ve } \\
\text { araştırma gibi laboratuar aktivitelerine yaşatıldığı süreçlerdir. Kurulmak istenen bağlam ve } \\
\text { kavram arasındaki ilişki bu ortamlarda yaparak yaşarak ögrenilmeye çalışılır. }\end{array}$ \\
\hline & $\begin{array}{l}\text { Öğrenci bağlam ve kavram arasındaki ilişkiyi tecrübe ettikten sonra bağlamın mesleki } \\
\text { boyutuna vurgu yapılır. Yani öğrencinin konuyu öğrenme sebebi, konuyu öğrenmesi için } \\
\text { gereken ihtiyaç aslında bu aşamada daha çok ön plana çıkmaktadır. Çünkü bağlam ve } \\
\text { kavram arasındaki ilişki öğrencinin meslek hayatında ne gibi uygulamalarda kullanılacağ1 } \\
\text { bu süreçte elde edilmeye çalışılır. Yine farklı materyaller, sınıf içi etkinlikler kullanılarak, } \\
\text { geziler düzenlenerek, gerçekçi senaryolar kurularak, problem çözme aktiviteleri yapılarak } \\
\text { bu öğrenme aktivitelerinin konuyla ilgili yönleri vurgulanmalıdır. Ayrıca öğretmen } \\
\text { öğrencilerin yeteneklerini göz önünde bulundurarak zor ama yapılması mümkün görevler } \\
\text { verebilir. }\end{array}$ \\
\hline $\begin{array}{l}\text { İş birliği } \\
\text { (Cooperating) }\end{array}$ & $\begin{array}{l}\text { Öğrencilerin arkadaşları ile iletişimde bulundukları ve öğrendiklerini paylaştıkları ve } \\
\text { tartıştıkları süreçtir. Her ögrencinin farklı bir özelliğinin bir araya getirilmesi ile küçük grup } \\
\text { çalışmaları yapılır. Öğretmen gruplara bir takım laboratuar aktiviteleri yaptırabilir veya bir } \\
\text { takım görevler verebilir. Bu süreçte her grup üyesine farklı görevler verir ve her üyenin } \\
\text { kendine olan güvenini ortaya çıarmaya ve derse olan motivasyonu sağlamaya çalışır. } \\
\text { Öğrenci grup başarılı olamazsa kendisinin başarılı olamayacağını bilmelidir ve görevler eşit } \\
\text { paylaşılmalıdır. Ortaya çıkan ürünü de sunmalarına fırsat verilmelidir. }\end{array}$ \\
\hline & $\begin{array}{l}\text { Transfer etme öğrencinin öğrendiğini yeni bir bağlamda veya yeni bir durumda } \\
\text { kullanabilmesidir. Transfer etme ilişkilendirmeye benzer. Sadece öğrenci öğrendiğini } \\
\text { transfer edebilmesi için öğretim sürecinde tartışılmayan bir bağlam veya durumla } \\
\text { karş1laşması gerekmektedir. }\end{array}$ \\
\hline
\end{tabular}


REACT stratejisine göre tasarlanan öğretimde animasyonlardan, örnek olaylardan ve çalışma yapraklarından yararlanılmıştır. Öğretim materyalinde sıcak hava balonu ve çalışma prensibi ana bağlam olarak kullanılmış ve materyaller birçok bağlamla zenginleştirilmiştir. Araştırma kapsamında geliştirilen ve deney grubunda REACT stratejisine göre yürütülen öğretim materyali (Kirman Bilgin, 2015) Tablo 2'deki gibi özetlenmiştir.

Tablo 2. Deney grubunda uygulanan öğretim materyalleri

\begin{tabular}{|c|c|}
\hline REACT & Öğretim Materyalleri \\
\hline $\mathrm{R}$ & $\begin{array}{l}\text { Sıcak Hava Balonlarının uçması için bu balonlarda meydana gelen değişmelerle ilgili } \\
\text { okuma parçası verilmiş ve ilgili sorularla ön bilgiler ortaya çıkarılmaya tartışılmıştır. } \\
\text { Bu balonlarda meydana gelen değişmelere yönelik animasyon izletilmiş ve fiziksel- } \\
\text { kimyasal değişme kavramlarıyla ilgili temel özellikler tartışılmıştır ( } 2 \text { ders). }\end{array}$ \\
\hline E & $\begin{array}{l}\text { Naftalinin süblimleşmesinin ve mumun erimesinin ele alındığı iki adet çalışma yaprağ } \\
\text { kullanılarak öğrencilerin kavramla ilgili tecrübe sahibi olmaları sağlanmıştır ( } 1 \text { ders). }\end{array}$ \\
\hline A & $\begin{array}{l}\text { Besin zehirlenmelerine karşı son tüketim tarihlerinin önemi, kumdan cam elde edilmesi } \\
\text { ve camın kırılması örnek olaylarını içeren, kavramla ilgili mesleklerin ve soruların yer } \\
\text { aldığı bir okuma parçası kullanılmıştır ( } 1 \text { ders }) \text {. }\end{array}$ \\
\hline $\mathrm{C}$ & $\begin{array}{l}\text { Petrolden benzine olan yolculuğu içeren bir örnek olay kullanılarak kavramla ilgili } \\
\text { mesleklerin incelendiği bir grup çalışması yürütülmüştür ( } 1 \text { ders). }\end{array}$ \\
\hline $\mathrm{T}$ & $\begin{array}{l}\text { Ekmek israfının yapılmaması gerektiği teması üzerinde duran ve buğdaydan ekmeğe } \\
\text { olan yolculuğu ele alan bir örnek olay incelenmiş ve sınıf içerisinde tartışılmıştır (1 } \\
\text { ders). }\end{array}$ \\
\hline
\end{tabular}

Kontrol grubunda Milli Eğitim Bakanlığı'nın (MEB) dağıttığı kitabın (Öcal, 2014) 78-83. sayfaları arasında yer alan etkinlikler gerçekleştirilmiştir. Ders öğretmeninin uyguladığı etkinlikler Tablo 3'deki gibi özetlenmektedir.

Tablo 3. Kontrol grubunda uygulanan öğretim materyalleri

\begin{tabular}{|c|c|}
\hline Ders & Etkinlik \\
\hline 1. & $\begin{array}{l}\text { s.78 de camın kırılması, elmanın kararması gibi örneklerin yer aldığı giriş sayfası okutulmuştur. } \\
\text { İlgili sorular tartışılmıştır. S.79 yer alan “Aynı madde farklı görüntü” etkinliğini yapmıştır. Bu } \\
\text { etkinlikte fındığın ezilmiş ve ezilmemiş hallerinin tadına bakılarak aynı madde olup olmadıkları } \\
\text { tespit edilmeye çalışılmıştır. Buradan fiziksel değişime değinilmiştir. }\end{array}$ \\
\hline 2. & $\begin{array}{l}\text { S. 80'de geri dönüşüme yönelik olan okuma parçası okutuluş ve "tekrar tekrar kullanılabilme" } \\
\text { genellemesiyle fiziksel değişim açıklanmaya çalışılmıştır. Muzun kararması elmanın kararması } \\
\text { gibi olaylarla kimyasal değişim açıklanmaya çalışılmıstır. Sonrasında s.83 deki değerlendirme } \\
\text { etkinliği yapılmıştır. }\end{array}$ \\
\hline 3. & Konuyla ilgili çoktan seçmeli sorulardan oluşan test dağıtılmış ve cevapları tartışılmıştır. \\
\hline 4. & Konuyla ilgili çoktan seçmeli sorulardan oluşan test dağıtılmış ve cevapları tartışılmıştır. \\
\hline 5. & Konuyla ilgili çoktan seçmeli sorulardan oluşan test dağıtılmış ve cevapları tartışılmıştır. \\
\hline 6. & Konuyla ilgili çoktan seçmeli sorulardan oluşan test dağıtılmış ve cevapları tartışılmıştır. \\
\hline
\end{tabular}


Kontrol grubunda yürütülen etkinlikler incelendiğinde uygulama öğretmeni ilk olarak konularla ilgili dikkat çekmiş ve sonrasında kazanımlarla ilgili açıklamalarda bulunmuştur. Öğretmen konuyla ilgili açıklamalarda bulunduktan sonra deney yapmış ve deneylerden sonra değerlendirme etkinliklerine yer vermiştir. Uygulama öğretmeninin izlediği bu öğretimin, öğretmen merkezli öğretime benzediği söylenebilir.

Her iki grupta da öğretim uygulamaları öğretim programında belirtildiği ders saati dikkate alınarak yürütülmüş ve toplam 6 ders saati sürmüştür.

Veri Toplama Araçları: Öğrencilere günlük hayatımızda sıkça rastladığımız 4 adet bağlam yöneltilmiştir. Bunlardan 2'si bağlam testi olarak 2'si de mülakat olarak uygulanmıştır. Bağlam testinde yer alan sorular iki aşamalı sorulardan oluşmaktadır (Bkz. Tablo 4). İlk aşamasında öğrencilerden, bırakılan boşluğa doğru düşündükleri cevapları yazmaları istenmektedir. İkinci aşamasında ise yazdıkları cevabın nedenini açıklamaları beklenmektedir. Mülakat soruları ise yarı yapılandırılmış şekilde sorulmuştur.

Tablo 4. Bağlam testinde yer alan bağlam 1 ve 2

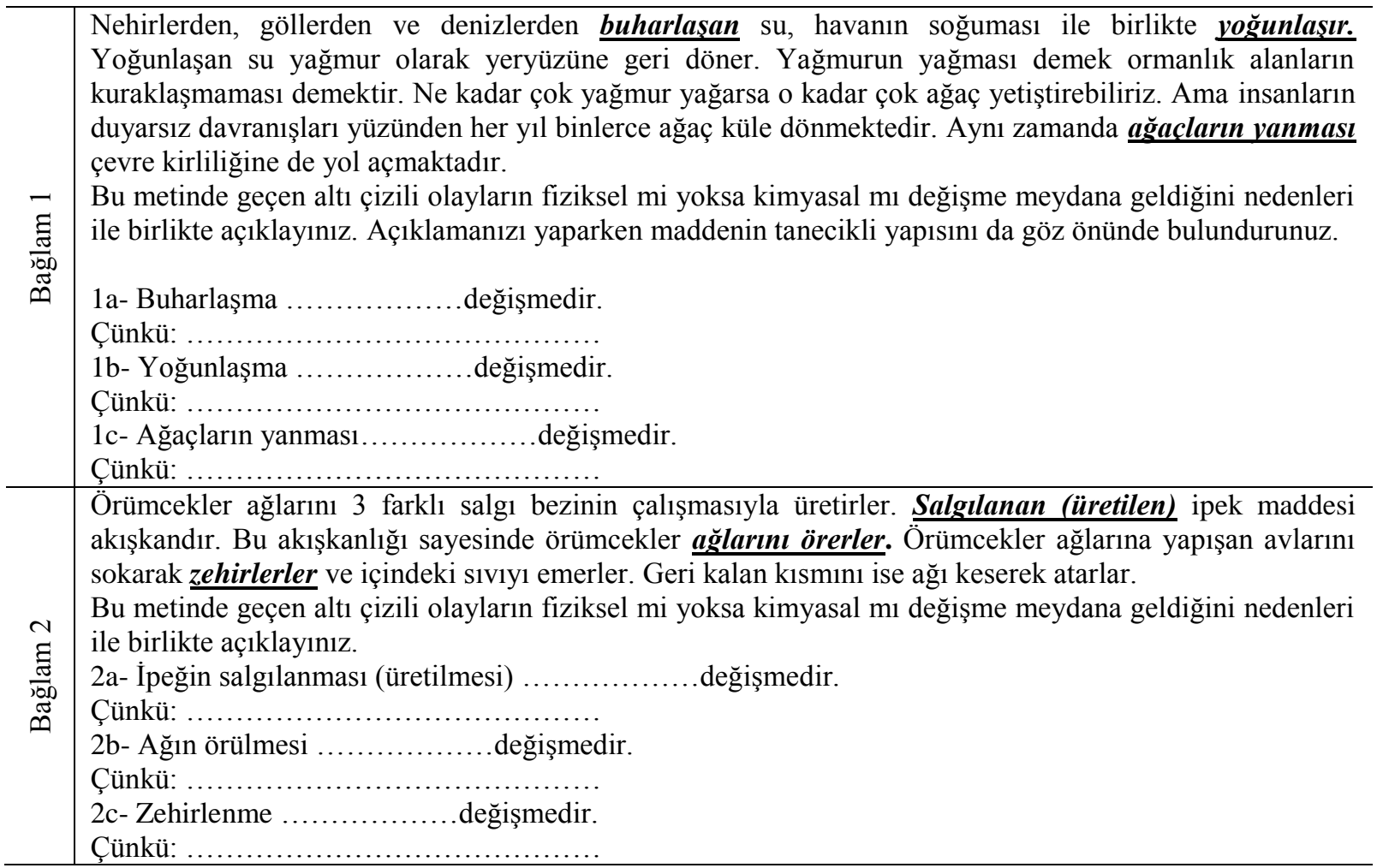


Bağlam testi öğrencilere ön, son ve gecikmiş test (uygulama bittikten 10 hafta sonra) olmak üzere üç defa uygulanmıştır. Mülakatlar ise öğretimlerden önce ve sonra uygulanmıştır. Mülakatta yer alan bağlamlar Tablo 5'deki gibidir.

Tablo 5. Mülakatlarda yer alan bağlam 3 ve 4

\begin{tabular}{|c|c|}
\hline 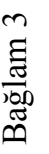 & Yumurtanın bozulması hangi tür değişmedir? \\
\hline 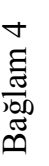 & $\begin{array}{l}\text { Ağaçlar kesilerek kütük haline getirilir. Kütüklerin dış yüzeyindeki } \underline{\text { kabuk soyulur. }} \text { Bu kütükler daha } \\
\text { ince kesilir ve kâğıt hamuru oluşturulur. Bu hamur bir süre } \underline{\text { kurutulur}} \text {. Sonrasında istenilen sekil } \\
\text { verilir. Ağacın kâğıda yolculuğunda altılı çizili olaylarda ne tür değişmeler olmuştur? Maddenin } \\
\text { tanecikli yapısını düşünerek cevaplandırınız. }\end{array}$ \\
\hline
\end{tabular}

Yöneltilen bu bağlamların maddenin tanecikli yapısını düşünerek cevaplamaları istenmiştir, çünkü fiziksel-kimyasal değişme kavramları "Maddenin Yapısı ve Özellikleri" ünitesinin ikinci konusunda yer almakta ve maddenin tanecikli yapısı konusu çerçevesinde öğrencilere kavratılmaktadır.

Geçerlik ve Güvenirlik Çalışmaları: Araştırmacı tarafından geliştirilen sıcak hava balonu ve çalışma prensibi bağlamı, öğrenci rehber materyali ve veri toplama araçları konu kazanımları dikkate alınarak; bir kimya bölümü, üç kimya eğitimi, bir fizik eğitimi ve iki fen bilimleri eğitimi alanlarında toplam 7 uzmanın görüşleri çerçevesinde şekillendirilmiştir. Geçerlik çalışmaları biten veri toplama araçlarının güvenirlik çalışmaları, 7. sınıf öğrencileriyle (N=40) yürütülmüştür. Gerekli düzenlemeler yapılarak (Kirman Bilgin, 2015) sorulara son hali verilmiştir. 
Verilerin analizinde ise araştırmacı tarafından rastgele beş öğrenci seçilmiştir. Öğrencilerden elde edilen veriler araştırmacı tarafından kodlanmıştır. Rastgele seçilen beş öğrencinin yanıtları iki kimya eğitimi, bir fen bilimleri eğitimi alanında uzman olan üç akademisyen tarafından ayrı ayrı kodlanmış ve araştırmacının kodlarıyla karşılaştırılmıştır. Araştırmacının ve uzmanların uzlaştıkları soru özellikleri çerçevesinde diğer veriler araştırmacı tarafından analiz edilmiştir.

Veri Analizi: Bağlam testi iki adet iki aşamalı soru içermektedir. İlk aşamasına doğru yanıt veren öğrenci "1" puan, yanlış cevap veren veya cevap vermeyen öğrenci "0" puan almaktadır. Soruların ikinci aşaması ise Marek (1986)'in açık uçlu soruların analizinde kullanmış olduğu puanlamanın uyarlanmasıyla oluşturulan yeni sisteme göre analiz edilmiştir. Bu puanlama sistemi Tablo 6'da belirtilmektedir. Tablo 6'dan yararlanılarak bağlam testinden elde edilen puanlar Mann Whitney-U testine tabi tutulmuştur.

Tablo 6. Açık uçlu soruların analizinde kullanılan puanlama

\begin{tabular}{c|c|c|l}
\hline Kategoriler & Kod & Puan & \multicolumn{1}{|c}{ İçerikleri } \\
\hline Tam İlişkilendirme & A & 3 & $\begin{array}{l}\text { Tanecik boyutunda bilimsel olarak doğru ilişkilendirme içeren } \\
\text { cevap }\end{array}$ \\
\hline Kısmi İlişkilendirme & B & 2 & $\begin{array}{l}\text { Makroskobik düzeyde ilişkilendirme yapan veya doğru } \\
\text { ilişkilendirmenin bir kısminı belirten cevap }\end{array}$ \\
\hline $\begin{array}{c}\text { Alternatif kavrama içeren } \\
\text { İlişkilendirme }\end{array}$ & C & 1 & $\begin{array}{l}\text { Bilimsel bilgilerle tutarlı olmayan, alternatif düşünceler içeren } \\
\text { ilişkilendirme }\end{array}$ \\
\hline İlişkilendirememe & D & 0 & Bilmiyorum şeklinde cevaplama, ilişkilendirme yapmama \\
\hline
\end{tabular}

Bağlam 1 ve 2'den elde edilen verilerin hangi kategoride değerlendirildiğine dair örnek öğrenci yanıtları Tablo 7'deki gibi özetlenmiştir. Alternatif kavrama içeren ilişkilendirmelerin hepsi ise Tablo 10 ve 12 'de belirtilmiştir.

Tablo 7. Kategorilere göre örnek öğrenci yanıtları

\begin{tabular}{c|l}
\hline Kategoriler & \multicolumn{1}{c}{ Örnek Öğrenci Yanıtları } \\
\hline Tam İlişkilendirme & $\begin{array}{l}\text { *Buharlaşma ve yoğunlaşma bir hal değiştirme olayıdır. Hal değiştirme olaylarında sadece } \\
\text { taneciklerin enerjisi ve aralarındaki boşluk değişir. Kimliği değişmez. Bu yüzden fiziksel } \\
\text { değişmedir. } \\
* \text { Ağacın yapısı bozulur ve kimliği değişir. Bu yüzden kimyasal değişmedir. }\end{array}$ \\
\hline
\end{tabular}




\begin{tabular}{c|l}
\hline & *Salgı bezlerinin salglladıkları maddelerin yapısı bozularak ipeği oluştururlar. Maddelerin \\
& kimliği değiştiği için kimyasal değişmedir. \\
& *Ağın yapısı bozulmaz ve kimliği değişmez. Bu yüzden fiziksel değişmedir. \\
& *Zehir, hücrelerin yapısını bozar ve oradaki maddelerin kimliğini değiştirir. Bu yüzden \\
& zehirlenme olayı kimyasal değişmedir. \\
\hline Kısmi & * Maddenin kimliği değişmediği için fiziksel değişmedir. \\
İlişkilendirme & * Maddenin kimliği değiştiği için kimyasal değişmedir. \\
\hline İlişkilendirememe & *Gözle göremediğimiz şeyler olduğu için kimyasal değişmedir. \\
& * Çevreye zarar verdiği için kimyasal değişmedir. \\
& * Ağın örülmesini gözle görebiliyoruz. Bu yüzden fiziksel değişmedir. \\
& *Zehirlenme olayını göremeyiz. Bu yüzden kimyasal değişmedir. \\
\hline
\end{tabular}

Mülakatlardan elde edilen verilerde Tablo 6'da yer alan sisteme göre analiz edilmiştir.

\section{Bulgular}

$\mathrm{Bu}$ bölümde bağlam testinden ve mülakatlardan elde edilen veriler ayrı ayrı sunulmaktadir.

Bağlam testinden elde edilen bulgular: Öğrencilerin bağlam testine verdikleri cevapların Mann Whitney U-testi sonuçları Tablo 8'deki gibidir.

Tablo 8. Bağlam testinden elde edilen verilerin $U$ testi sonuçları

\begin{tabular}{ccccccc}
\hline Test & Grup & $\mathrm{N}$ & Sira ortalamas1 & Sira toplamı & $\mathrm{U}$ & $\mathrm{p}$ \\
\hline \multirow{2}{*}{ Ön test } & Deney & 50 & 43,43 & 2171,50 & 896,50 &, 060 \\
\cline { 2 - 7 } & Kontrol & 51 & 48,42 & 2979,50 & & \\
\hline \multirow{2}{*}{ Son test } & Deney & 50 & 59,09 & 2954,50 & 870,50 &, 006 \\
\cline { 2 - 7 } & Kontrol & 51 & 43,07 & 2196,50 & & \\
\hline \multirow{2}{*}{ Gecikmiş test } & Deney & 50 & 56,59 & 2829,50 & 995,50 &, 047 \\
\cline { 2 - 7 } & Kontrol & 51 & 45,52 & 2321,50 & & \\
\hline
\end{tabular}

Tablo 8 incelendiğinde grupların ön test sonuçlarının birbirine yakın olduğu görülmektedir. Fakat son test $(U=870,50, p<.05)$ ve gecikmiş test $(U=995,50, p<.05)$ uygulamaları incelendiğinde gruplar arasında REACT stratejisine göre yürütülen öğretim uygulamalarının yer aldığı deney grubu lehine anlamlı farklılık olduğu dikkat çekmektedir. Grupların puan ortalamaları ise aşağıdaki grafikte sunulmaktadır. 


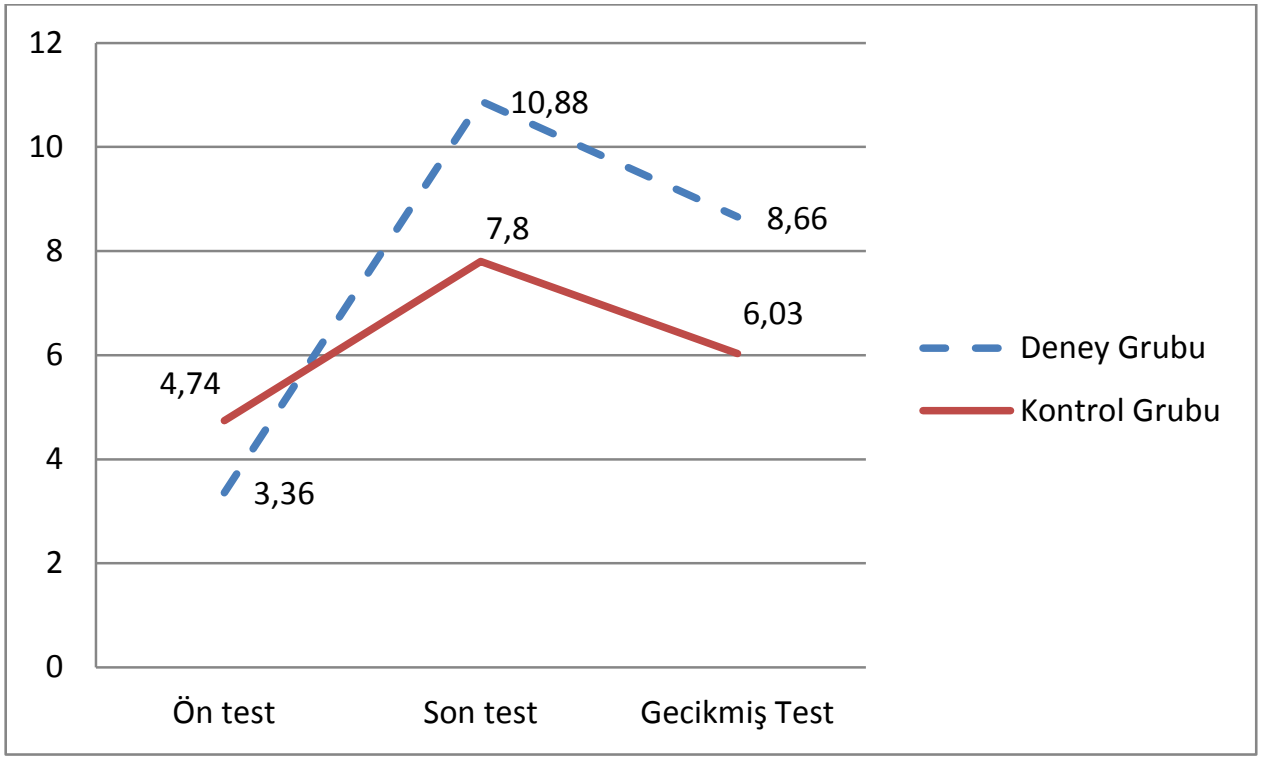

Grafik 1. Deney ve kontrol grubunun test ortalamaları

Grafik 1 incelendiğinde deney grubunun puan ortalamasının kontrol grubuna göre hem son hem de gecikmiş testte daha yüksek olduğu dikkat çekmektedir.

Grupların bağlam 1'e verdikleri yanıtlardan elde edilen nitel veriler ise Tablo 9'daki gibi özetlenmiştir.

Tablo 9. Bağlam 1'e verilen cevapların frekans dağılımları

\begin{tabular}{|c|c|c|c|c|c|c|c|c|c|c|}
\hline \multirow{3}{*}{$\begin{array}{l}\text { I. Aşamada Yer Alan } \\
\text { İfade }\end{array}$} & & & \multicolumn{8}{|c|}{ II. Aşama (Gerekçe) } \\
\hline & \multirow{2}{*}{\multicolumn{2}{|c|}{ I. Aşama }} & \multicolumn{4}{|c|}{ Deney Grubu (f) } & \multicolumn{4}{|c|}{ Kontrol Grubu (f) } \\
\hline & & & A & $\mathrm{B}$ & $\mathrm{C}$ & $\mathrm{D}$ & A & $\mathrm{B}$ & $\mathrm{C}$ & $\mathrm{D}$ \\
\hline \multirow{9}{*}{$\begin{array}{l}\text { 1a- Buharlaşma } \\
\text {......... değişmedir. }\end{array}$} & \multirow{3}{*}{$\begin{array}{l}\text { Ön } \\
\text { Test }\end{array}$} & $F$ & 1 & - & 4 & 10 & - & - & 1 & 25 \\
\hline & & $\mathrm{K}$ & - & - & 3 & 16 & - & - & 7 & 16 \\
\hline & & $\mathrm{B}$ & - & - & - & 16 & - & - & - & 2 \\
\hline & \multirow{3}{*}{$\begin{array}{l}\text { Son } \\
\text { Test }\end{array}$} & $F$ & 8 & 17 & 1 & 12 & 3 & 6 & 10 & 19 \\
\hline & & $\mathrm{K}$ & - & - & 7 & 3 & - & - & 3 & 6 \\
\hline & & B & - & - & - & 2 & - & - & - & 4 \\
\hline & \multirow{3}{*}{$\begin{array}{l}\text { Gecikmiş } \\
\text { Test }\end{array}$} & $F$ & 2 & 15 & 1 & 11 & - & 6 & 8 & 19 \\
\hline & & $\mathrm{K}$ & - & - & 4 & 11 & - & - & 3 & 8 \\
\hline & & B & - & - & - & 6 & - & - & - & 7 \\
\hline \multirow{9}{*}{$\begin{array}{l}\text { 1b-Yoğunlaşma } \\
\text {......... değişmedir. }\end{array}$} & \multirow{3}{*}{$\begin{array}{l}\text { Ön } \\
\text { Test }\end{array}$} & $F$ & 1 & - & 3 & 17 & - & 1 & 1 & 24 \\
\hline & & $\mathrm{K}$ & - & - & 1 & 10 & - & - & - & 21 \\
\hline & & B & - & - & - & 18 & - & - & - & 4 \\
\hline & \multirow{3}{*}{$\begin{array}{l}\text { Son } \\
\text { Test }\end{array}$} & $F$ & 8 & 20 & - & 13 & 3 & 7 & 5 & 21 \\
\hline & & $\mathrm{K}$ & - & 1 & 1 & 5 & - & - & 1 & 8 \\
\hline & & B & - & - & - & 2 & - & - & - & 6 \\
\hline & \multirow{3}{*}{$\begin{array}{c}\text { Gecikmiş } \\
\text { Test }\end{array}$} & $F$ & 2 & 18 & 2 & 13 & - & 7 & 5 & 20 \\
\hline & & $\mathrm{K}$ & - & - & 2 & 6 & - & - & 2 & 10 \\
\hline & & B & - & - & - & 7 & - & - & - & 7 \\
\hline
\end{tabular}




\begin{tabular}{|c|c|c|c|c|c|c|c|c|c|c|}
\hline \multirow{9}{*}{$\begin{array}{l}\text { 1c-Ağaçların yanması } \\
\text {......... değişmedir. }\end{array}$} & \multirow{3}{*}{$\begin{array}{l}\text { Ön } \\
\text { Test }\end{array}$} & $\mathrm{F}$ & - & - & 3 & 16 & - & - & 4 & 14 \\
\hline & & $K$ & 1 & - & 5 & 9 & - & 1 & 9 & 20 \\
\hline & & B & - & - & - & 16 & - & - & - & 3 \\
\hline & \multirow{3}{*}{$\begin{array}{l}\text { Son } \\
\text { Test }\end{array}$} & $\mathrm{F}$ & - & - & - & 2 & - & - & - & 2 \\
\hline & & $K$ & 10 & 17 & 4 & 15 & 4 & 5 & 15 & 22 \\
\hline & & B & - & - & - & 2 & - & - & - & 3 \\
\hline & \multirow{3}{*}{$\begin{array}{l}\text { Gecikmiş } \\
\text { Test }\end{array}$} & $\mathrm{F}$ & - & - & 2 & 5 & - & - & 2 & 7 \\
\hline & & $K$ & 4 & 17 & 5 & 13 & 1 & 6 & 12 & 19 \\
\hline & & B & - & - & - & 4 & - & - & - & 4 \\
\hline
\end{tabular}

A: Tam İlişskilendirme B: Kısmi İlişkilendirme C: Alternatif kavrama içeren İlişkilendirme D: İlişkilendirememe
F: Fiziksel Değişme
K: Kimyasal Değişme
B: Bilmiyorum-Boş

Tablo 9 incelendiğinde son test sonucunda bağlamlarla kavramlar arasında tam ve kısmi ilişkilendirme yapabilen deney grubu öğrencilerinin sayısının kontrol grubuna göre daha fazla olduğu görülmektedir. Deney ve kontrol gruplarının ilişkilendirme yaparken kullandıkları alternatif kavramalar Tablo 10'daki gibidir.

Tablo 10. Bağlam 1'den elde edilen alternatif kavramalar

\begin{tabular}{|c|c|c|c|c|c|c|c|}
\hline & \multirow[t]{2}{*}{ Alternatif Kavramalar } & \multicolumn{3}{|c|}{ Deney Grubu (f) } & \multicolumn{3}{|c|}{ Kontrol Grubu (f) } \\
\hline & & ÖT & ST & GT & ÖT & ST & GT \\
\hline \multirow{15}{*}{$\cong$} & İnsan bir şey yapmadan olduğu için fiziksel değişmedir & 1 & - & - & - & - & - \\
\hline & Tanecikler genleştiği için kimyasal değişmedir & 1 & - & - & - & - & - \\
\hline & Maddeler gaz olduğu için buharlaşma olayları kimyasal değişmedir & 3 & - & 1 & 4 & - & 2 \\
\hline & Bir tepkime gerçekleştiği için kimyasal değişmedir & 1 & - & - & - & - & - \\
\hline & Suyu geri kazanabiliriz. Bu yüzden buharlaşma fiziksel değişmedir & 1 & - & 1 & - & - & 3 \\
\hline & Buharlaşınca maddelerin kimliği değişir. Bu yüzden kimyasal değişmedir & - & 7 & 3 & - & - & - \\
\hline & Su isınınca içindeki tanecikler buhar olur. Bu yüzden fiziksel değişmedir & - & 1 & - & - & - & - \\
\hline & Madde şekil değiştirdiği için kimyasal değişmedir & - & - & - & 1 & - & - \\
\hline & Buharlaşma kendiliğinden olduğu için fiziksel değişmedir & - & - & - & 1 & - & - \\
\hline & Buharlaşırken kimyasal maddeye dönüştükleri için kimyasal değişmedir & - & - & - & 1 & - & - \\
\hline & Bir daha geri gelmeyeceği için kimyasal değişmedir & - & - & - & 1 & 1 & 1 \\
\hline & Madde eski haline dönebildiği için fiziksel değişmedir & - & - & - & - & 8 & 3 \\
\hline & Bir zaman sonra su kaybolur. Bu yüzden fiziksel değişmedir & - & - & - & - & 1 & - \\
\hline & Su artık gazdır ve havada kaybolur. Bu yüzden kimyasal değişmedir & - & - & - & - & 3 & 1 \\
\hline & İçine kimyasal bir madde konulmadan olduğu için fiziksel değişmedir & - & - & - & - & - & 1 \\
\hline \multirow{13}{*}{$=$} & İnsan bir şey yapmadan olduğu için fiziksel değişmedir & 1 & - & - & - & - & 1 \\
\hline & Tanecikli yap1 değiştiği için kimyasal değişmedir & - & - & 1 & - & - & - \\
\hline & Yoğunlaşırken tanecikler şişer. Bu yüzden kimyasal değişmedir & 1 & - & - & - & - & - \\
\hline & Maddenin içinde sıkışma olduğu için kimyasal değişmedir & 1 & - & - & - & - & - \\
\hline & Suyu geri kazanabiliriz. Bu yüzden yoğunlaşma fiziksel değişmedir & 1 & - & - & - & - & - \\
\hline & Madde yoğunlaşınca kimliği değişir. Bu yüzden kimyasal değişmedir & - & 1 & - & - & 1 & - \\
\hline & Kendiliğinden olduğu için fiziksel değişmedir & - & - & - & 1 & - & - \\
\hline & Madde eski haline dönebildiği için fiziksel değişmedir & - & - & 1 & - & 5 & 3 \\
\hline & Yoğunlaşan madde tekrar eski haline dönmediği için kimyasal değişmedir & - & - & - & - & - & 1 \\
\hline & Maddeye tanecik eklenip çıkarılmamıştır. Bu yüzden fiziksel değişmedir & - & - & 1 & - & - & - \\
\hline & Maddenin şekli değiştiği için kimyasal değişmedir & - & - & 1 & - & - & - \\
\hline & Maddenin yapısı değiştiği için kimyasal değişmedir & - & - & - & - & - & 1 \\
\hline & İçine kimyasal madde konulmadan olduğu için fiziksel değişmedir. & - & - & - & - & - & 1 \\
\hline \multirow{2}{*}{$\because$} & İnsan yaptığı için kimyasal değişmedir. & 2 & - & - & 3 & & 2 \\
\hline & İnsan yaptığı için fiziksel değişmedir & 1 & - & - & & - & - \\
\hline
\end{tabular}


Ağaçlar yanınca şekilleri değişir. Bu yüzden fiziksel değişmedir

Yangında bir tepkime olmadığı için fiziksel değişmedir

Ağaçlar bir daha eski haline geri dönemeyeceği için kimyasal değişmedir

Isı alınca maddenin kimliği değişir

Ağaçtaki tanecikler yanar ve tanecikler azaldığı için kimyasal değişmedir

Maddenin tanecikli yapısı artar. Bu yüzden kimyasal değişmedir

Tanecikler yanarak yok olduğu için maddenin kimliği değişir

Ağacı kimyasal bir madde yaktığı için kimyasal değişmedir

Ağaçlar yanınca görünümü değiştiği için kimyasal değişmedir

Ağaçlar yanınca kütlesi ve şekli değişir. Bu yüzden fiziksel değişmedir

Ağaçlar doğada tekrar oluşur. Bu yüzden fiziksel değişmedir

Ağaçlar yok olduğu için kimyasal değişmedir

Ağaçlar yok olduğu için fiziksel değişmedir

Tanecikler azaldığı için kimyasal değişmedir

ÖT: Ön test $\quad$ ST: Son test GT: Gecikmiş Test

Tablo 10 incelendiğinde öğretim uygulamaları sonunda deney grubunda alternatif kavramaya

sahip öğrenci sayısında azalma olduğu, kontrol grubunda ise bu sayının arttığı dikkat çekmektedir.

Deney ve kontrol grubu öğrencilerinin bağlam 2'ye verdikleri yanıtlardan elde edilen verilerin frekans dağılımları Tablo 11'de verilmiştir.

Tablo 11. Bağlam 2'ye verilen cevapların frekans dağılımları

\begin{tabular}{|c|c|c|c|c|c|c|c|c|c|c|}
\hline \multirow{3}{*}{ I. Aşamada Yer Alan İfade } & \multirow{2}{*}{\multicolumn{2}{|c|}{ I. Aşama }} & \multicolumn{8}{|c|}{ II. Aşama (Gerekçe) } \\
\hline & & & \multicolumn{4}{|c|}{ Deney Grubu (f) } & \multicolumn{4}{|c|}{ Kontrol Grubu (f) } \\
\hline & & & A & $\mathrm{B}$ & $\mathrm{C}$ & $\mathrm{D}$ & A & $\mathrm{B}$ & $\mathrm{C}$ & $\mathrm{D}$ \\
\hline \multirow{9}{*}{$\begin{array}{l}\text { 2a-İpeğin salgılanması } \\
\text { (üretilmesi) } \\
\text {...................değişmedir. }\end{array}$} & \multirow{3}{*}{$\begin{array}{l}\text { Ön } \\
\text { Test }\end{array}$} & $\mathrm{F}$ & - & - & 3 & 12 & - & - & - & 21 \\
\hline & & $K$ & - & 2 & - & 16 & - & 1 & 2 & 24 \\
\hline & & $\mathrm{B}$ & - & - & - & 17 & - & - & - & 3 \\
\hline & \multirow{3}{*}{$\begin{array}{l}\text { Son } \\
\text { Test }\end{array}$} & $\mathrm{F}$ & - & 1 & - & 24 & - & - & - & 21 \\
\hline & & $K$ & 3 & 8 & - & 9 & 2 & 2 & 5 & 18 \\
\hline & & B & - & - & - & 5 & - & - & - & 3 \\
\hline & \multirow{3}{*}{$\begin{array}{l}\text { Gecikmiş } \\
\text { Test }\end{array}$} & $\mathrm{F}$ & - & - & 1 & 18 & - & - & - & 24 \\
\hline & & $K$ & 1 & 11 & 2 & 11 & - & 1 & 4 & 17 \\
\hline & & B & - & - & - & 6 & - & - & - & 5 \\
\hline \multirow{9}{*}{$\begin{array}{l}\text { 2b-Ağın örülmesi } \ldots \ldots \ldots \ldots \ldots \\
\text { değişmedir. }\end{array}$} & \multirow{3}{*}{$\begin{array}{l}\text { Ön } \\
\text { Test }\end{array}$} & $F$ & 2 & 1 & 3 & 18 & 1 & 3 & - & 33 \\
\hline & & $\mathrm{K}$ & - & - & 1 & 9 & - & - & - & 11 \\
\hline & & B & - & - & - & 16 & - & - & - & 3 \\
\hline & \multirow{3}{*}{$\begin{array}{l}\text { Son } \\
\text { Test }\end{array}$} & $F$ & 7 & 16 & - & 16 & 2 & 6 & 7 & 28 \\
\hline & & $\mathrm{K}$ & - & - & - & 7 & - & - & - & 4 \\
\hline & & B & - & - & - & 4 & - & - & - & 4 \\
\hline & \multirow{3}{*}{$\begin{array}{l}\text { Gecikmiş } \\
\text { Test }\end{array}$} & $F$ & 4 & 14 & - & 19 & - & 3 & 11 & 24 \\
\hline & & $\mathrm{K}$ & - & 1 & 3 & 4 & - & - & 2 & 5 \\
\hline & & B & - & - & - & 5 & - & - & - & 6 \\
\hline \multirow{5}{*}{$\begin{array}{l}\text { 2c-Zehirlenme olayı } \ldots . . . \ldots \ldots \\
\text { değişmedir. }\end{array}$} & \multirow{3}{*}{$\begin{array}{l}\text { Ön } \\
\text { Test }\end{array}$} & $\mathrm{F}$ & - & - & - & 11 & - & - & - & 8 \\
\hline & & $K$ & - & 2 & 4 & 17 & - & 7 & 4 & 28 \\
\hline & & B & - & - & - & 16 & - & - & - & 4 \\
\hline & \multirow[b]{2}{*}{ Son } & $\mathrm{F}$ & - & - & 1 & 7 & - & - & 1 & 2 \\
\hline & & $K$ & 4 & 13 & - & 21 & 4 & 3 & 4 & 34 \\
\hline
\end{tabular}


ISSN:1305-020

\begin{tabular}{|c|c|c|c|c|c|c|c|c|c|}
\hline Test & B & - & - & - & 4 & - & - & - & 3 \\
\hline \multirow{3}{*}{$\begin{array}{c}\text { Gecikmiş } \\
\text { Test }\end{array}$} & $\mathrm{F}$ & - & - & 1 & 8 & - & - & 1 & 6 \\
\hline & $K$ & 2 & 7 & 1 & 25 & - & 3 & 6 & 29 \\
\hline & B & - & - & - & 6 & - & - & - & 6 \\
\hline
\end{tabular}

A: Tam İlişkilendirme B: Kısmi İlişkilendirme C: Alternatif kavrama içeren İlişkilendirme D: İlişkilendirememe F: Fiziksel Değişme

Son ve gecikmiş test sonuçları, REACT stratejisine göre öğretim uygulamaları yapılan deney grubu öğrencilerinin "tam ve kısmi ilişkilendirme" yapabilenlerin sayısının, fen bilimleri öğretmeninin ders planlarına göre dersin yürütüldüğü kontrol grubu öğrencilerine göre daha fazla olduğunu göstermektedir. Bağlam 2 çerçevesinde son ve gecikmiş test sonuçları incelendiğinde kontrol gurubu öğrencilerinin deney grubu öğrencilerine göre kavramlarla bağlamları ilişkilendirirken daha fazla alternatif kavrama ürettikleri görülmektedir. Tablo 11 incelendiğinde ilişkilendirme yapabilen her iki grupta da yer alan öğrencilerin çoğunluğunun kısmi ilişkilendirme yaptıkları dikkat çekmektedir.

Bağlam 2'den elde edilen alternatif kavramaların tümü Tablo 12'de belirtilmektedir.

Tablo 12. Bağlam 2'den elde edilen alternatif kavramalar

\begin{tabular}{|c|c|c|c|c|c|c|c|}
\hline & \multirow[t]{2}{*}{ Alternatif Kavramalar } & \multicolumn{3}{|c|}{ Deney Grubu (f) } & \multicolumn{3}{|c|}{ Kontrol Grubu (f) } \\
\hline & & ÖT & ST & GT & ÖT & ST & GT \\
\hline \multirow{6}{*}{$\sqrt{\mathrm{N}}$} & Örümcek tarafindan yapılıyor. Bu yüzden fiziksel değişmedir & 2 & - & 1 & - & - & - \\
\hline & Bir daha elde edebiliriz. Bu yüzden fiziksel değişmedir & 1 & - & - & - & - & - \\
\hline & Kimyasal maddelerden elde edildiği için kimyasal değişmedir & - & - & 1 & 2 & - & - \\
\hline & Madde eski haline tekrar dönemeyeceği için kimyasal değişmedir & - & - & - & - & 4 & 4 \\
\hline & Sıvıdan katıya dönüştüğü için kimyasal değişmedir & - & - & - & - & 1 & - \\
\hline & Tanecikler eklenerek oluştuğu için kimyasal değişmedir & - & - & 1 & - & - & - \\
\hline \multirow{8}{*}{ กิ } & Örümcek tarafindan yapılıyor. Bu yüzden fiziksel değişmedir & 3 & - & - & - & - & 1 \\
\hline & Tekrar eski haline dönemez. Bu yüzden kimyasal değişmedir & 1 & - & - & - & - & 1 \\
\hline & Eski haline dönebilir. Bu yüzden fiziksel değişmedir & - & - & - & - & 7 & 7 \\
\hline & Ağın şekli değişiyor. Bu yüzden kimyasal değişmedir & - & - & 1 & - & - & 1 \\
\hline & Ağı örerken başka bir madde katmadığı için fiziksel değişmedir & - & - & - & - & - & 2 \\
\hline & A ̆̆ yapışkandır. Yeniden örülemediği için kimyasal değişmedir & - & - & 1 & - & - & - \\
\hline & Ağın kimliği değiştiği için kimyasal değişmedir & - & - & 1 & - & - & - \\
\hline & Tanecikler ne artıyor ne azalıyor. Bu yüzden fiziksel değişmedir & - & - & - & - & - & 1 \\
\hline \multirow{8}{*}{$\ddot{\nu}$} & Zehir kimyasal bir madde olduğu için zehirlenme de kimyasal değişmedir & 3 & - & 1 & 4 & 1 & 2 \\
\hline & Bir daha elde edemeyiz. Bu yüzden kimyasal değişmedir & 1 & - & - & - & - & - \\
\hline & İnsan zehirlendiğinde tedavi olabildiği için fiziksel değişmedir & - & 1 & - & - & 1 & - \\
\hline & Zehirlenince eski halimize dönemediğimiz için kimyasal değişmedir & - & - & - & - & 2 & 3 \\
\hline & Tanecikler ölürler. Bu yüzden kimyasal değişmedir & - & - & - & - & 1 & 1 \\
\hline & Avın şekli değişmediği için kimyasal değişmedir & - & - & 1 & - & - & - \\
\hline & Tanecikler eklenmediği için fiziksel değişmedir & - & - & 1 & - & - & - \\
\hline & Zehri geri çıkarabiliriz. Bu yüzden fiziksel değişmedir & - & - & - & - & - & 1 \\
\hline
\end{tabular}


Uygulama sonrasında bağlam 2'den elde edilen veriler deney grubu öğrencilerinin ilişkilendirme yaparken alternatif kavrama kullanma durumlarını azalttığını göstermektedir. Kontrol grubunda ise fen bilimleri öğretmeninin öğretim uygulamaları sonrasında öğrencilerin bağlamlarla kavramları ilişkilendirirken alternatif kavrama kullanma durumlarında artış olduğu ortaya çıkmaktadır.

Mülakatlardan EIde Edilen Bulgular: Mülakatlar yoluyla öğrencilerin fen kavramları ile karşılaştıkları bağlamları ilişkilendirebilme durumlarını derinlemesine incelemek amaçlanmıştır. Elde edilen veriler Tablo 6'daki gibi kategorilere ayrılmış ve tablolara aktarılmıştır. Deney grubundan üst düzeyden birinci ve ikinci öğrenciler " $D_{\text {Ü2}}, D_{\text {Ü35", orta }}$ düzeydeki öğrenciler " $\mathrm{D}_{\mathrm{O} 17}, \mathrm{D}_{\mathrm{O} 48}$ ” ve alt düzeydeki öğrenciler " $\mathrm{D}_{\mathrm{A} 15}, \mathrm{D}_{\mathrm{A} 50}$ ", kontrol grubu öğrencileri ise “ $\mathrm{K}_{\mathrm{U} 17}, \mathrm{~K}_{\mathrm{U} 27}, \mathrm{~K}_{\mathrm{O} 9}, \mathrm{~K}_{\mathrm{O} 47}, \mathrm{~K}_{\mathrm{A} 33}, \mathrm{~K}_{\mathrm{A} 25}$ ” şeklinde kodlanmıştır.

Mülakatın 1. sorusu olan bağlam 3'den elde edilen bulgular Tablo 13'deki gibi sunulmuştur.

Tablo 13. Bağlam 3'den elde edilen öğrenci açıklamalarına ait bulgular

\begin{tabular}{|c|c|c|c|}
\hline Bağlam & & Ön Mülakat & Son Mülakat \\
\hline \multirow{4}{*}{$\begin{array}{l}\text { 3-Yumurtanın } \\
\text { bozulması } \\
\text { hangi tür } \\
\text { değişmedir? } \\
\text { Neden? }\end{array}$} & A & - & $\begin{array}{l}\text { Maddenin yapis1 bozulur. Bozulunca da } \\
\text { kimliği değişir. } \mathrm{Bu} \text { yüzden kimyasal } \\
\text { değişmedir. }\left(\mathrm{D}_{\mathrm{A} 50}, \mathrm{D}_{\mathrm{O} 48}-\mathrm{K}_{\mathrm{U} 27}\right)\end{array}$ \\
\hline & B & $\begin{array}{l}\text { Kimyasal değişmedir. Çünkü çürümüştür. } \\
\text { İçinde başka şeyler oluşmuştur. ( } \mathrm{K}_{\mathrm{O} 9}- \\
\left.\mathrm{D}_{\mathrm{Ü35}}, \mathrm{D}_{\mathrm{O} 48}\right) \\
\text { Farklı bir madde yapısına girdiği için } \\
\text { kimyasal değişmedir. }\left(\mathrm{D}_{\mathrm{O} 17}\right)\end{array}$ & $\begin{array}{l}\text { Kimliği değiştiği için kimyasal değişmedir. } \\
\left(\mathrm{D}_{\mathrm{A} 15}, \mathrm{D}_{\mathrm{O} 17}, \mathrm{D}_{\mathrm{U} 2,35}-\mathrm{K}_{\mathrm{O} 47}, \mathrm{~K}_{\mathrm{Ü17}}\right) \\
\text { Çürüdüğü için kimyasal değişmedir. }\left(\mathrm{K}_{\mathrm{O} 9}\right)\end{array}$ \\
\hline & $\mathrm{C}$ & $\begin{array}{l}\text { İçinin görünümü değiştiği için kimyasal } \\
\text { değişmedir. }\left(\mathrm{D}_{\mathrm{Ü} 2}\right) \\
\text { Icçine bir şey katmadığımız için fiziksel } \\
\text { değimedir. }\left(\mathrm{D}_{\mathrm{A} 50}\right)\end{array}$ & $\begin{array}{l}\text { Kendi kendine bozulduğu için fizikseldir. } \\
\left(\mathrm{K}_{\mathrm{A} 25}\right)\end{array}$ \\
\hline & $\mathrm{D}$ & $\begin{array}{l}\text { Nedenini bilmiyorum ama kimyasal } \\
\text { değişmedir. }\left(\mathrm{K}_{\mathrm{U} 17}, \mathrm{~K}_{\mathrm{O} 47}-\mathrm{D}_{\mathrm{A} 15}\right) \\
\text { İçindeki mikroplar arttığ }) \\
\left.\text { değişin kimedir. ( } \mathrm{K}_{\mathrm{Ü2}}\right) \\
\text { İçinde sarı bir şey var, bozulunca onu } \\
\text { yiyemiyoruz. }\left(\mathrm{K}_{\mathrm{A} 25}\right) \\
\text { Fiziksel değişmedir. Çünkü yumurtaları } \\
\text { yiyoruz. }\left(\mathrm{K}_{\mathrm{A} 33}\right)\end{array}$ & Bilmiyorum. $\left(\mathrm{K}_{\mathrm{A} 33}\right)$ \\
\hline
\end{tabular}


Tablo 13 incelendiğinde Bağlam 3'e son mülakatta deney grubu öğrencilerinin “Tam veya kısmi İlişkilendirme" kategorisinde yanıt verdikleri görülmektedir. Mülakatın 2. sorusu olan Bağlam 4'den elde edilen bulgular aşağıdaki gibi sunulmuştur.

Tablo 14. Bağlam 4'den elde edilen öğrenci açıklamalarına ait bulgular

\begin{tabular}{|c|c|c|c|}
\hline Bağlam & & Ön Mülakat & Son Mülakat \\
\hline \multirow{4}{*}{$\begin{array}{l}\text { 4a- } \\
\text { Ağaçların } \\
\text { kesilmesi ne } \\
\text { tür bir } \\
\text { değişmedir? } \\
\text { Neden? }\end{array}$} & $\mathrm{A}$ & ( & $\begin{array}{l}\text { Maddenin yap1s1 bozulmadığı için kimliği değişmez. } \\
\text { Bu yüzden fiziksel değişmedir. }\left(\mathrm{D}_{\mathrm{A} 50}-\mathrm{K}_{\mathrm{U} 27}\right)\end{array}$ \\
\hline & $\mathrm{B}$ & - & $\begin{array}{l}\text { Kimliği değişmediği için fiziksel değişmedir. ( } \mathrm{D}_{\text {Ü2 } 235}, \\
\left.\mathrm{D}_{\mathrm{O} 17,48}-\mathrm{K}_{\mathrm{U} 17}, \mathrm{~K}_{09,47}\right)\end{array}$ \\
\hline & $\mathrm{C}$ & $\begin{array}{l}\text { Ağacin görünümünde değişiklik olduğu için } \\
\text { fiziksel değişmedir. }\left(\mathrm{K}_{\text {Ü27 }}-\mathrm{D}_{\text {Ü2}}\right) \\
\text { Bizim ürettiğimiz şeylerle kestiğimiz için } \\
\text { kimyasal değişmedir. }\left(\mathrm{D}_{\mathrm{O} 17}\right) \\
\text { Kendiliğinden gerçekleşmediği için fiziksel } \\
\text { değişmedir. }\left(\mathrm{D}_{\mathrm{A} 50}\right)\end{array}$ & 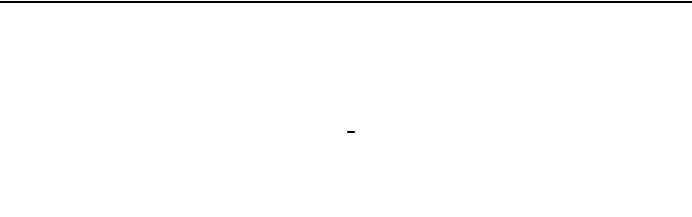 \\
\hline & $\mathrm{D}$ & $\begin{array}{l}\text { Nedenini bilmiyorum ama fiziksel değişmedir. } \\
\left(\mathrm{K}_{\mathrm{U} 17}, \mathrm{~K}_{\mathrm{O} 9,47}-\mathrm{D}_{\mathrm{A} 15}\right) \\
\text { Bilmiyorum. }\left(\mathrm{K}_{\mathrm{A} 25,33}-\mathrm{D}_{\mathrm{Ü35}}\right) \\
\text { Çürüme olay1 olmadığ1 için fiziksel değişmedir. } \\
\left(\mathrm{D}_{\mathrm{O} 48}\right)\end{array}$ & $\begin{array}{l}\text { Kesilince ağacın bir anlamı kalmadığı için kimyasal } \\
\text { değişmedir. }\left(\mathrm{D}_{\mathrm{A} 15}\right) \\
\text { Nedenini bilmiyorum ama ağacın kesilmesi kimyasal } \\
\text { değişmedir. }\left(\mathrm{K}_{\mathrm{A} 25}\right) \\
\text { Nedenini bilmiyorum ama fiziksel değişmedir. }\left(\mathrm{K}_{\mathrm{A} 33}\right)\end{array}$ \\
\hline \multirow{4}{*}{$\begin{array}{l}\text { 4b- } \\
\text { Kütüklerin } \\
\text { kabuklarının } \\
\text { soyulması } \\
\text { ne tür bir } \\
\text { değişmedir? } \\
\text { Neden? }\end{array}$} & $\mathrm{A}$ & 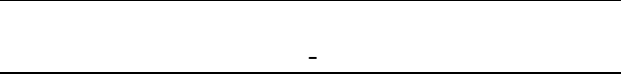 & $\begin{array}{l}\text { Maddenin yapısı bozulmadığı için kimliği değişmez. } \\
\text { Bu yüzden fiziksel değişmedir. }\left(\mathrm{K}_{\mathrm{U} 27}\right)\end{array}$ \\
\hline & $\mathrm{B}$ & - & $\begin{array}{l}\text { Kimliği değişmediği için fiziksel değişmedir. ( } \mathrm{D}_{\mathrm{Ü} 2,35}, \\
\left.\mathrm{D}_{\mathrm{O} 17,48}, \mathrm{D}_{\mathrm{A} 15,50}-\mathrm{K}_{\mathrm{O} 9,47}, \mathrm{~K}_{\mathrm{U} 17}\right)\end{array}$ \\
\hline & $\mathrm{C}$ & $\begin{array}{l}\text { Görünümü değiştiği için fiziksel değişmedir. } \\
\left(K_{U ̈ 17}-D_{U ̈ 2}\right) \\
\text { Kendiliğinden gerçekleşmediği için fiziksel } \\
\text { değişmedir. }\left(\mathrm{D}_{\mathrm{A} 50}\right)\end{array}$ & $\begin{array}{l}\text { Kendiliğinden olmadığı için kimyasal değişmedir. } \\
\left(\mathrm{K}_{\mathrm{A} 33}\right)\end{array}$ \\
\hline & $\mathrm{D}$ & $\begin{array}{l}\text { Kabuk işe yaramadığ } \text { için kimyasal } \\
\text { değişmedir. }\left(\mathrm{K}_{\text {Ŭ27 }}\right) \\
\text { Nedenini bilmiyorum ama fiziksel değişmedir. } \\
\left(\mathrm{K}_{\mathrm{O} 9,47}-\mathrm{D}_{\mathrm{Ü35}}, \mathrm{D}_{\mathrm{A} 15}\right) \\
\text { Nedenini bilmiyorum ama kimyasal } \\
\text { değişmedir. }\left(\mathrm{K}_{\mathrm{A} 25}-\mathrm{D}_{\mathrm{O} 17}\right) \\
\text { İçindeki yeşil renkli s1v1 dişarı çıktığ için } \\
\text { kimyasal değişmedir. }\left(\mathrm{K}_{\mathrm{A} 33}\right) \\
\text { Çürüme olayı olmadığ1 için fiziksel değişmedir. } \\
\left(\mathrm{D}_{\mathrm{O} 48}\right)\end{array}$ & $\begin{array}{l}\text { Nedenini bilmiyorum ama ağacın kesilmesi kimyasal } \\
\text { değişmedir. }\left(\mathrm{K}_{\mathrm{A} 25}\right)\end{array}$ \\
\hline \multirow{6}{*}{$\begin{array}{l}\text { 4c-Kağıt } \\
\text { hamurunun } \\
\text { kurutulmas } \\
\text { ne tür bir } \\
\text { değişmedir? } \\
\text { Neden? }\end{array}$} & $\mathrm{A}$ & e & $\begin{array}{l}\text { İçindeki su buharlaşıyor. Kimliği değişmiyor. Bu } \\
\text { yüzden fiziksel değişmedir. }\left(\mathrm{D}_{\mathrm{U} 2}, \mathrm{D}_{\mathrm{O} 17}-\mathrm{K}_{\mathrm{U} 17,27}\right)\end{array}$ \\
\hline & & $\begin{array}{l}\text { Kuruduğu zaman sadece şekli değiştiği için } \\
\text { fiziksel değişmedir. }\left(\mathrm{K}_{\mathrm{U} 27}\right)\end{array}$ & $\begin{array}{l}\text { Kimliği değişmediği için fiziksel değişmedir. ( } D_{\text {Ü35 }} \text {, } \\
\left.D_{A 15,50}-K_{09,47}\right)\end{array}$ \\
\hline & $\mathrm{C}$ & $\begin{array}{l}\text { İçine bir şey katmadıkları için fiziksel } \\
\text { değişmedir. }\left(\mathrm{D}_{\mathrm{U} 2}, \mathrm{D}_{\mathrm{A} 50}\right)\end{array}$ & - \\
\hline & $\mathrm{D}$ & $\begin{array}{l}\text { Bilmiyorum. }\left(\mathrm{K}_{\mathrm{U} 17}, \mathrm{~K}_{\mathrm{O} 9}-\mathrm{D}_{\mathrm{U} 35}\right) \\
\text { Nedeninin bilmiyorum ama kimyasal } \\
\text { değişmedir. }\left(\mathrm{K}_{\mathrm{O} 47}, \mathrm{~K}_{\mathrm{A} 33}-\mathrm{D}_{\mathrm{A} 15}\right) \\
\text { Kuruyunca sertleştiği için kimyasal değişmedir. } \\
\left(\mathrm{K}_{\mathrm{A} 25}\right) \\
\text { Kuruyunca sertleştiği için fiziksel değişmedir. } \\
\left(\mathrm{D}_{\mathrm{O} 48}\right) \\
\text { Başkas1 kuruttuğu için kimyasal değişmedir. } \\
\left(\mathrm{D}_{\mathrm{O} 17}\right)\end{array}$ & $\begin{array}{l}\left.\text { Yapısı değiştiği için kimyasal değişmedir. ( } \mathrm{D}_{\mathrm{O} 48}\right) \\
\text { Bilmiyorum. }\left(\mathrm{K}_{\mathrm{A} 25,33}\right)\end{array}$ \\
\hline & A & ( & $\begin{array}{l}\text { Maddenin yapısı bozulmadığı için kimliği değişmez. } \\
\text { Bu yüzden fiziksel değişmedir. }\left(\mathrm{D}_{\mathrm{A} 50}-\mathrm{K}_{\mathrm{O} 9,47}, \mathrm{~K}_{\mathrm{Ü1}}\right)\end{array}$ \\
\hline & B & $\begin{array}{l}\text { Sadece şeklinde bir değişiklik olduğu için } \\
\text { fiziksel değişmedir. }\left(\mathrm{K}_{\mathrm{U} 17,27}-\mathrm{D}_{\ddot{U} 35}\right)\end{array}$ & $\begin{array}{l}\text { Kimliği değişmediği için fiziksel değişmedir. ( } \mathrm{D}_{\text {Ü2,35, }} \text {, } \\
\left.\mathrm{D}_{\mathrm{O} 17,48}, \mathrm{D}_{\mathrm{A} 15}-\mathrm{K}_{\text {Ü27 }}\right)\end{array}$ \\
\hline
\end{tabular}




\begin{tabular}{|c|c|c|c|}
\hline $\begin{array}{l}\text { 4d-Kağit } \\
\text { hamura }\end{array}$ & $\mathrm{C}$ & $\begin{array}{l}\text { İçine bir şey katmadığımız için fiziksel } \\
\text { değişmedir. (DA50) }\end{array}$ & - \\
\hline $\begin{array}{l}\text { şekil } \\
\text { verilmesi ne } \\
\text { tür bir } \\
\text { değişmedir? } \\
\text { Neden? }\end{array}$ & D & $\begin{array}{l}\text { Bilmiyorum }\left(\mathrm{K}_{\mathrm{O} 9}-\mathrm{D}_{\mathrm{U} 2}\right) \\
\text { Nedeninin bilmiyorum ama kimyasal } \\
\text { değişmedir. }\left(\mathrm{K}_{\mathrm{A} 33}, \mathrm{~K}_{\mathrm{O} 47}\right) \\
\text { Nedenini bilmiyorum ama fiziksel değişmedir. } \\
\left(\mathrm{D}_{\mathrm{O} 17}, 48, \mathrm{D}_{\mathrm{A} 15}\right) \\
\text { Ezdikleri için fiziksel değişmedir. }\left(\mathrm{K}_{\mathrm{A} 25}\right)\end{array}$ & $\begin{array}{l}\text { Nedenini bilmiyorum ama ağacın kesilmesi kimyasal } \\
\text { değişmedir. }\left(\mathrm{K}_{\mathrm{A} 25,33}\right)\end{array}$ \\
\hline
\end{tabular}

Tablo 14 incelendiğinde 4a. sorusuna deney grubu öğrencilerinin çoğunun son mülakatta "Tam ve kısmi ilişkilendirme" yaptıkları dikkat çekmektedir.

Bağlam testinden ve mülakatlardan elde edilen bulgular çerçevesinde araştırmaya konu olan kavramlar ve öğretim uygulamalarına yönelik yapılan tartışma bir sonraki bölümde yer almaktadir.

\section{Tartışma}

Bağlam testinin iki aşamalı sorularından elde edilen ön test sonuçları öğrencilerin fen kavramları ile bağlamları ilişkilendirme durumlarının birbirine yakın olduğunu göstermektedir. Gerçekleştirilen öğretimlerin etkililiğini ortaya çıkarmak adına yapılan son ve gecikmiş test sonuçlarında (Tablo 8 - Grafik 1) deney grubunda yürütülen REACT stratejisinin uygulama öğretmeninin hazırladığı ders planlarına göre daha etkili olduğu görülmektedir. "Sıcak Hava Balonu ve Çalışma Prensibi” bağlamı ve REACT'ın her basamağında ayrı ayrı yürütülen bağlamsal öğrenmeye dayalı etkinliklerin, deney grubu öğrencilerinin fiziksel ve kimyasal değişme kavramları ile bağlamları ilişkilendirebilme durumlarını olumlu yönde etkilediği ve kontrol grubuna göre daha başarılı olmasını sağladığı söylenebilir.

Bağlam 1, buharlaşma, yoğunlaşma ve yanma olaylarını içermektedir. Yanıtlar incelendiğinde her iki grubun ön teste göre son ve gecikmiş test sonuçlarında ilişkilendirme yapan öğrencilerde artış olduğu görülmektedir. Öğrencilerin çoğunluğu yağmurun yağması için gerekli olan buharlaşma ve yoğunlaşma olaylarını hal değişimi ile ilişkilendirmiş ve 
fiziksel değişme olduğunu açıklamışlardır. Fakat kontrol grubunda daha çok olmak üzere deney grubunda da öğrencilerin yağmurun yağmasının hal değiştirme olayları olan buharlaşma ve yoğunlaşma kavramlarını konuyla ilişkilendirirken alternatif kavramalara sahip oldukları tespit edilmiştir. Alternatif kavramaya sahip olan deney grubu öğrencilerinin çoğunluğu buharlaşınca maddenin kimliğinin değiştiğini, su 1sınınca taneciklerin buhar olduğunu düşünmektedir. Yine kontrol grubuna bakıldığında öğrencilerin, maddelerin buharlaşınca gaza dönüştüklerini ve havada kaybolduklarını düşündükleri görülmektedir. Literatür incelendiğinde ilgili alternatif kavramaların birçok çalışmada da tespit edildiği dikkat çekmektedir (Adbo ve Taber, 2009; Ceylan ve Geban, 2009; Henriques, 2002; Krnel, Watson ve Glažar, 1998; Tsitsipis, Stamovlasis ve Papageorgiou, 2010). Öğrencilerin maddenin hal değiştirmesiyle birlikte tanecikli yapısındaki meydana gelen değişmeleri zihninde yanlış yapılandırması hal değiştirme olaylarını kimyasal değișme olarak düşünmesine yol açmaktadır (Chang, Quintana ve Krajcık, 2010; Demircioğlu, Demircioğlu, Ayas ve Kongur; 2012). Deney grubunda buharlaşma ve yoğunlaşma olaylarını fiziksel değişme kavramıyla ilişkilendirebilenlerin sayısının kontrol grubuna göre daha çok olduğu dikkat çekmektedir. Bunun sebebi REACT'ın her basamağında bağlamsal öğrenmeye yer verilmiş olması ve hal değiştirme olaylarına yönelik farklı bağlamların tartışılmasından kaynaklanıyor olabilir.

Alternatif kavramaya sahip kontrol grubundaki öğrencilerin çoğu madde eski haline dönebildiği için fiziksel değişmedir düşüncesine sahiptir. Öğrenciler yanan ağacin yerinden yeni bir ağacın çıkacağını düşünüyor ve ağaç tekrar elde edilebildiği için bu olayın fiziksel değişme olduğu çıkarımında bulunuyor olabilirler. Yine alternatif kavramaya sahip kontrol grubunda yer alan öğrencilerin çoğu ağaçlar bir daha eski haline geri dönemeyeceği için kimyasal değişmedir düşüncesine sahiptir. Bu düşünce de ders öğretmeninin ve ders kitabının 
belirttiği genelleme sonucunda oluştuğu söylenebilir. Öğretmenlerin ders kitabını detaylı incelemeleri ve öğrenciyi alternatif kavramaya sürükleyecek yorumlarda bulunmamaları ve gerekirse kitaptaki bilgileri öğrencilere düzelttirmeleri gerekmektedir. Ders kitabında yer alan ifade Şekil 1'deki gibidir.

Deneyde kâğıdı yaktınz. Bu işlem sonunda kâğıdın ilk durumundan çok farklı bir maddeje, kole doneştọ̆ano gözlemlediniz. Ouşan kôlleri, tekrar kåğt hâline getirmeniz mümkan degildir. Bu durumda,

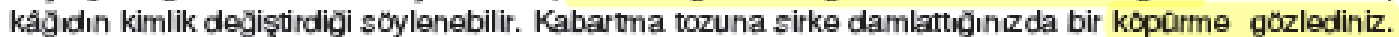
Kecilmiş elmayı beklettiğinizde, karardıðını yani çorodogono gözlemlediniz. Tôm bu degişimlerde maddelerin kimlik degiştirdiğini gözlemlediniz. Bu şekilde bir maddenin çeşitli etkilerle baş̧ka maddelere dônoşmesine kimyasal değişim denir. Etkinlikte olduŏu gibi kimyasal degiş̧imler sırasında, bazı deఏişimler gozlemlenir. Bu degişimler, ısı, ışık, gaz çıkışı ve renk degişimleridir. Metallerin paslanması sârecinde bu degisşimler gözlemlenmese de paslanma olayı kimyasal değişimdir.

Şekil 1. 6. sınıf ders kitabında yer alan konuyla ilgili açıklama

Şekil 1'de renkli belirtilen bölümlerde yer alan tekrar geri getirme - köpürme - gaz çıkışı ve renk değişimleri gibi ifadelerin öğrencilerin sahip oldukları alternatif kavramaların nedeni olarak görülebilir. Buradan ders kitaplarının öğrencilerin kavramsal değişim süreçlerinde ne kadar önemli bir rolünün olduğu görülmektedir (Aşçı, Özkan ve Tekkaya, 2001; Kikas, 1998). Uygulama öğretmeninin ders kitabında Şekil 1'deki gibi yer alan, alternatif kavrama içeren bilgileri (Öcal, 2014, s.82) tespit edip ders planlarını doğru şekillendirmesi öğrencilerin bilimsel bilgileri zihinlerinde doğru yapılandırması açısından önemlidir. Uygulama öğretmeninin bu durumu fark etmemesi kendisinin de alternatif kavramaya sahip olduğunun bir göstergesi olabilir. İlgili literatür incelendiğinde öğretmenlerinde alternatif kavramalara sahip olduğunu ve öğrencilerin kavramsal değişim süreçlerini olumsuz etkiledikleri görülmektedir (Aydoğan Güneş ve Gülçiçek, 2003; Yağbasan ve Gülçiçiek, 2003).

Alternatif kavramaya sahip deney grubu öğrencilerinin bazılarının "ağaçtaki tanecikler yanar ve tanecikler azalır ve Tanecikler yanarak yok olduğu için maddenin kimliği 
değişir düşüncelerine sahip olduğu görülmektedir. Öğrenciler yanma olayında maddenin kimliğini değiştirerek başka maddelerin oluştuğunu düşünememektedir. Yine A $\breve{g} a c ̧ l a r ~ y o k$ olduğu için kimyasal değişmedir alternatif kavramasına da her iki grupta da rastlanmıştır. Bu düşüncenin sebebi orman yangınlarına karşı yürütülen etkinliklerde, televizyon programlarında ormanlarımızı yok etmeyelim şeklindeki ifadelerin etkili olduğu söylenebilir.

Bağlam 2, ipeğin salgılanması, ağın örülmesi ve zehirlenme olaylarını içermektedir. Tablo 11 incelendiğinde deney grubu öğrencileri soruda yer alan olayları kontrol grubu öğrencilerine göre fiziksel ve kimyasal değişme ile daha yüksek oranda ilişkilendirebildiği görülmektedir. Aynı zamanda bağlam 2 kavramlarla bağlamları ilişkilendirmede deney grubunda yürütülen öğretim materyalinin daha başarılı olduğunun ortaya çıktığı sorudur. Çünkü kontrol grubunun son ve gecikmiş test sonuçları incelendiğinde bağlam 1'de görülen başkası tarafindan yapılma - tekrar geri getirme veya getirememe - tanecik artmasl, azalması ve ölmesi gibi düşüncelere rastlanmaktadır. Bu genellemelere ek olarak hem deney grubunda hem de kontrol grubunda ise zehir kimyasal bir madde olduğu için zehirlenme de kimyasal değişmedir ve kimyasal maddelerden elde edildiği için kimyasal dĕgişmedir alternatif kavramaları ortaya çıkmıştır. Maddelerin insan sağlığına zararı olma durumunu göz önünde bulundurarak maddede meydana gelen değişimi belirlemek istemeleri günlük hayatımızda kullandığımız kimyasal madde kelimesinden kaynaklanıyor olabilir. Yine bağlam 1'de Bir madde buharlaşırken kimyasal bir maddeye dönüşür, bu yüzden kimyasal değişmedir, içine kimyasal bir madde konulmadan olduğu için fiziksel değişmedir” ve ağacı kimyasal bir madde yaktığı için kimyasal değişmedir alternatif kavramalarına rastlanmıştır. Tespit edilen bu alternatif kavramalar günlük yaşantımızın ve çevrenin bilimsel bilgilerin kavranmasında ne kadar etkili olduğunun bir göstergesidir. 
Ders kitabında yer alan ve uygulama öğretmeninin ifade ettiği alternatif kavrama kontrol grubundaki öğrencilerde ipeğin salgılanması (üretilmesi) olayında madde eski haline tekrar dönemeyeceği için kimyasal değişmedir, ağın örülmesi olayında tekrar eski haline dönemez, bu yüzden kimyasal değişmedir, zehirlenme olayında insan zehirlendiğinde tedavi olabildiği için fiziksel değişmedir ve zehri geri çıkarabiliriz, bu yüzden fiziksel değişmedir alternatif kavramalarının ortaya çıkmasına neden olmuştur. Bu yüzden öğretmenlerin güncel bilgileri takip etmesi önemlidir.

Bağlam 1 ve 2'ye verilen yanıtlar incelendiğinde her iki grupta da alternatif kavrama içeren ilişkilendirme yapan öğrencilerin bir kısmının, birisi tarafından müdahale edilme kendiliğinden olma gibi durumları göz önünde bulundurarak maddede meydana gelen değişimleri açıklamaya çalıştıkları tespit edilmiştir. Bu düşüncelerde yine çevrenin etkisiyle olaşan genellemelerden kaynaklandığı söylenebilir. Çünkü ağaçların yanması olayında insanların ağaçlara zarar verdiğini düşünmeleri insanların dışarıdan bir etki olduğunu ve dışarıdan bir etki olduğunda kimyasal değişme olacağını düşünmelerine neden olmuş olabilir. Çünkü ipeğin salgılanması ve ağın örülmesinde örümcek yaptı̆̆ı için fiziksel de ğişmedir alternatif kavraması yer almaktadır. Öğrencilerin bağlamların kavramlarla olan ilişkisini çözmek için alternatif kavramalara yönelmiş oldukları görülmektedir. $\mathrm{Bu}$ yüzden gerçekleştirilecek olan öğretimlerin bağlamlar çerçevesinde gerçekleşmesi öğrencilerin çevrelerinde meydana gelen olayları daha iyi anlamalarına ve yorumlamalarına neden olacaktır. Bağlam temelli öğrenmenin savunduğu gibi alternatif kavramaların bilimsel bilgilerle değiştirilmesi için günlük hayatla ilişkilendirmeye vurgu yapılması ve bağlamların öğrenilecek kavramlarla ilişkilendirilerek açıklanması önemlidir (Gilbert, 2006).

Son mülakat sonuçları incelendiğinde deney grubundan gerek üst ve orta gerekse alt gruptan olan öğrencilerin verilen olayları neden fiziksel ve kimyasal değişme olduklarını 
açıklayabildikleri görülmektedir. Fakat kontrol grubu öğrencilerin de öğretim sonrası bazı alternatif kavramaların olduğu tespit edilmiştir. Bu öğrenciler dışarıdan olaylara dışarıdan bir etki olma durumunu göz önünde bulundurarak maddede meydana gelen değişimleri sınıflamaya çalışmışlardır. Dolayısıyla REACT stratejisine dayalı öğretimin öğrencilerin fiziksel-kimyasal değişme kavramlarının bağlamlarla ilişkilendirebilmelerini olumlu yönde etkilediği söylenebilir. Çünkü bağlam temelli öğrenme ortamları karşılaşılan bir olayın veya sorunun çözümü için fen kavramlarını ve kavramlar arası ilişkileri bir araç olarak kullanır (Acar ve Yaman, 2011).

\section{Sonuc}

REACT stratejisine göre geliştirilen öğretim materyallerinin öğrencilerin fiziksel ve kimyasal değişme kavramlarını bağlamlarla ilişkilendirebilme durumları üzerinde kontrol grubunda yürütülen etkinliklere göre daha etkili ve daha kalıcı olduğu tespit edilmiştir. Fakat edilen nitel bulgular incelendiğinde öğrencilerin tam ilişkilendirmeden daha çok kısmi ilişkilendirme yapabildikleri görülmektedir. $\mathrm{Bu}$ durum öğrencilerin fiziksel ve kimyasal değişme kavramlarını makroskobik boyutta kavradıklarını göstermektedir. Araştırmadan elde edilen diğer bir sonuç ise öğrencilerin hal değiştirme olaylarında maddenin kimliğinin ve yapısının değiştiğini düşündükleridir. Aynı zamanda öğrenciler meydana gelen değişimleri, karşılaştıkları maddelerin yararlı ve zararlı olmasıyla, birisi tarafindan müdahale edilme veya kendiliğinden olma, tekrar geri getirme gibi özelliklerle ilişkilendirmekte ve çoğunlukla da genellemelere gidererek alternatif kavrama oluşturmaktadırlar. Araştırmadan elde edilen bu sonuçlar, ön öğrenmelerin ve çevreden elde edilen bilgilerin sonraki öğrenmeler için ne kadar etkili olduğunu göstermektedir.

\section{Öneriler}


Araştırma sonucunda öğrencilerin, hal değiştirme olaylarını fiziksel değişme olarak kavramakta zorluk çektikleri belirlenmiştir. Bir sonraki araştırmalarda fiziksel değişmenin tanımı ve verilen örneklerin, bütün hal değiștirme olaylarına yönelik ayrı ayrı bağlamlar içeren öğretim materyallerinin geliştirilmesi önerilebilir. Öğrencilerin sağlığa zararlı olan maddelerde meydana gelen değişmeleri kimyasal değişme ile ilişkilendirdikleri belirlenmiştir. Geliştirilen öğretim materyalinin uygulama, işbirliği veya transfer etme basamaklarına bu alternatif kavramaya yönelik bağlamlar eklenerek öğretim zenginleştirilebilir.

\section{Makalenin Bilimdeki Konumu (Yeri)}

Matematik ve Fen Bilimleri Eğitimi Bölümü - Fen Bilimleri Eğitimi Anabilim Dalı

\section{Makalenin Bilimdeki Özgünlüğü}

$\mathrm{Bu}$ araştırma sonucunda öğretmenler; günlük hayat deneyimlerinin öğrencilerin fen kavramlarını öğrenmeleri üzerinde ne kadar etkili olduğundan, öğrencilerin karşılaştıkları günlük hayat deneyimlerini açıklarken nasıl bir yol izlediklerinden, fiziksel ve kimyasal değişme konusunu bağlamlarla nasıl ilişkilendirdiklerinden, ilişkilendirirken hangi alternatif kavramalar ürettiklerinden haberdar olacaklardır. Aynı zamanda bu araştırma, fen bilimleri öğretmenlerine fen bilimleri alanındaki güncel bilgileri takip etme yükümlülükleri olduğunu ve ders kitaplarını bu güncel bilgiler çerçevesinde incelemeleri gerektiğini fark ettirecektir.

\section{Kaynaklar}


Acar, B. ve Yaman, M. (2011). Bağlam temelli öğrenmenin öğrencilerin ilgi ve bilgi düzeylerine etkisi. Hacettepe Üniversitesi Eğitim Fakültesi Dergisi, 40, 1-10.

Adbo, K. and Taber, K. S. (2009). Learners' mental models of the particle nature of matter: A study of 16-year-old Swedish science students. International Journal of Science Education, 31(6), 757-786.

Ahtee, M. and Varjola, I. (1998). Students' understanding of chemical reaction. International Journal of Science Education, 20(3), 305-316.

Aşçı, Z., Özkan, Ş. ve Tekkaya, C. (2001). Students' misconceptions about respiration. Eğitim ve Bilim, 26(120), 29-36.

Atasoy, B., Genç, E., Kadayıfcı, H. ve Akkuş, H. (2007). 7. sınıf öğrencilerinin fiziksel ve kimyasal değişmeler konusunu anlamalarında iş birlikli öğrenmenin etkisi. Hacettepe Üniversitesi Ë̆itim Fakültesi Dergisi, 32, 12-21.

Aydoğan, S., Güneş, B. ve Gülçiçek, Ç. (2003). Isı ve sıcaklık konusunda kavram yanılgıları. Gazi Eğitim Fakültesi Dergisi, 23(2), 111-124.

Ayvac1, H. Ş., Er Nas, S. ve Dilber, Y. (2016). Bağlam temelli rehber materyallerin öğrencilerin kavramsal anlamaları üzerine etkisi: “İletken ve Yalıtkan Maddeler" Örneği. Yüzüncü Yıl Üniversitesi Eğitim Fakültesi Dergisi, 13(1), 51-78.

Bakırc1, H., Subay, S., Midyatlı, F. ve Ünsal, N. (2010). İlköğretim ikinci kademe öğrencilerinin bazı fen kavramlarıyla ilgili düşüncelerinin sınıf seviyesi ne göre incelenmesi. Abant İzet Baysal Üniversitesi Dergisi, 10(1), 31-48.

Boujaoude, S. B. (1992). The relationship between students' learning strategies and the change in their misunderstandings during a high school chemistry course. Journal of Research in Science Teaching, 29(7), 687-699. 
Ceylan, E. ve Geban, O. (2009). Maddenin yoğun fazları ve çözünürlük kavramlarını anlamada 5E öğrenme modelinin kullanımı ile kavramsal değişimin kolaylaştırılması. Hacettepe Üniversitesi Eğitim Fakültesi Dergisi, 36, 41-50.

Chang, H. Y., Quintana, C. and Krajcik, J. S. (2010). The impact of designing and evaluating molecular animations on how well middle school students understand the particulate nature of matter. Science Education, 94(1), 73-94.

Coştu, B., Ayas, A. ve Ünal, S. (2007). Kavram yanılgıları ve olası nedenleri: Kaynama kavramı. Kastamonu Ĕ̈itim Dergisi, 15(1), 123-136.

Crawford, M. and Witte M. (1999). Strategies for mathematics: teaching in context, Educational Leadership, 57(3), 34-38.

Crawford, M. L. (2001). Teaching contextually: research, rationale, and techniques for 1mproving student motivation and achievement in mathematics and science, CCI Publishing, Waco, Texas.

Çalık, M, ve Ayas, A. (2005). 7.-10. sınıf öğrencilerinin seçilen çözelti kavramlarıyla ilgili anlamalarının farklı karışımlar üzerinde incelenmesi, Türk Eğitim Bilimleri Dergisi, 3(3), 329-349.

Demircioğlu, H., Demircioğlu, G., Ayas, A. ve Kongur, S. (2012). Onuncu sinıf öğrencilerinin fiziksel ve kimyasal değişme kavramları ile ilgili teorik ve uygulama bilgilerinin karşılaştırılması. Türk Fen Eğitimi Dergisi, 9(1), 162-181.

Demircioğlu, G., Özmen, H. ve Demircioğlu, H. (2006). Sınıf öğretmeni adaylarının fiziksel ve kimyasal değişme kavramlarını anlama düzeyleri ve yanılgıları. Milli Eğitim Dergisi, 170(35), 260-273. 
Demircioğlu, H., Vural, S. ve Demircioğlu, G. (2012). REACT stratejisine uygun hazırlanan materyalin üstün yetenekli öğrencilerin başarısı üzerine etkisi. Ondokuz Mayıs Üniversitesi Ĕ̈itim Fakültesi Dergisi, 31(2), 101-144.

Driver, R. (1988). Changing conceptions. Adolescent development and school science, 161198.

Eilks, I., Moellering, J. and Valanides, N. (2007). Seventh-grade students' understanding of chemical reactions-Reflections from an action research interview study. Eurasia Journal of Mathematics, Science \& Technology Education, 3(4), 271-286.

Er Nas, S., Şenel Çoruhlu, T. and Kirman Bilgin, A. (2016). The effect of fire context on the conceptual understanding of students: expansion-contraction. Educational Research and Reviews, 11(21), 1973-1985.

Gilbert, J. K. (2006). On the nature of "context" in chemical education. International Journal of Science Education, 28(9), 957-976.

Gilbert, J. K., Bulte, A. M. and Pilot, A. (2011). Concept development and transfer in context-based science education. International Journal of Science Education, 33(6), $817-837$.

Goodwin, C. (2000). Action and embodiment within situated human interaction. Journal of pragmatics, 32(10), 1489-1522.

Henriques, L. (2002). Children's ideas about weather: A review of the literature. School Science and Mathematics, 102(5), 202-215.

Hull, D. (1999). Teaching mathematics contextually, The Cornerstone of Tech Prep. CORD Communications, Inc., Waco, Texas. 
Ingram, S. J. (2003). The effects of contextual learning instruction on science achievement of male and female tenth grade students, Phd Thesis, University of South Alabama, Instructional Design and Development, ABD.

Johnson, P. (1998). Children's understanding of changes of state involving the gas state, part 1: Boiling water and the particle theory, International Journal of Science Education, 20(5), 567-583.

Kikas, E. (1998). The impact of teaching on students' definitions and explanations of astronomical phenomena. Learning and Instruction, 8(5), 439-454.

King, D. T., Winner, E. and Ginns, I. (2011). Outcomes and implications of one teacher's approach to context-based science in the middle years. Teaching Science, 57(2), 26-30.

Kirman Bilgin, A. (2015). “Maddenin Yapısı ve Özellikleri” ünitesi kapsamında REACT stratejisine yönelik tasarlanan öğretim materyallerinin etkililiğinin değerlendirilmesi. Yayınlanmamış doktora tezi, Karadeniz Teknik Üniversitesi, Trabzon.

Krnel, D., Watson, R. and Glažar, S. A. (1998). Survey of research related to the development of the concept of 'matter'. International Journal of Science Education, 20(3), 257-289.

Marek, E. A. (1986). They misunderstand, but they'll pass. The Science Teacher, 32-35.

Mayoh, K. and Knutton, S. (1997). Using out-of-school experience in science lessons: reality or rhetoric?. International Journal of Science Education, 19(7), 849-867.

Morrison, G. R., Ross, S. M., Kemp, J. E. and Kalman, H. (2010). Designing effective instruction. (6rd Edition). Wiley. com.

Navarra, A. (2006). Achieving pedagogical equity in the classroom. CORD Publishing. Waco, Texas, USA. 
Novak, J. D. (1988). Learning science and the science of learning. Studies in Science Education, 15, 77-101.

Novak, J. D. and Musonda, D. (1991). A twelve-year longitudinal study of science concept learning. American Educational Research Journal, 28(1), 117-153.

Nussbaum, J. and Novick, S. (1982). Alternative frameworks, conceptual conflict and accommodation: Toward a principled teaching strategy. Instructional science, 11(3), 183-200.

Othman, J., Treagust, D. F. and Chandrasegaran, A. L. (2008). An investigation into the relationship between students' conceptions of the particulate nature of matter and their understanding of chemical bonding. International Journal of Science Education, $30(11), 1531-1550$.

Öcal, C. (2014). Ortaokul Fen Bilimleri 6. Sınıf Ders Kitabı, s, 85-96. (Ed: Hülya Özdoğan). Fenbil Yayınc1lık, İstanbul.

Özmen, H. (2003). Kimya öğretmen adaylarının asit ve baz kavramlarıyla ilgili bilgilerini günlük olaylarla ilişkilendirme düzeyleri. Gazi Üniversitesi Kastamonu Eğitim Dergisi, 11(2), 317-324.

Özmen, H. and Ayas, A. (2003). Students' difficulties in understanding of the conservation of matter in open and closed-system chemical reactions. Chemistry Education Research and Practice, 4(3), 279-290.

Richey, R. C. (2000). The future role of Robert M. Gagné in instructional design. The Legacy of Robert M. Gagne, 255-281.

Solsona, N. R., Izquierdo, M. and De Jong, O. (2003). Exploring the development of students' conceptual profiles of chemical change. International Journal of Science Education, $25(1), 3-12$. 
Sökmen, N., Bayram, H. ve Yılmaz, A. (2000). 5., 8. ve 9. sınıf öğrencilerinin fiziksel değişim ve kimyasal değişim kavramlarını anlama seviyeleri. M. Ü. Atatürk Ĕ̆itim Bilimleri Dergisi, 12, 261-266.

Stavridou, H. and Solomonidou, C. (1998). Conceptual reorganization and the construction of the chemical reaction concept during secondary education. International Journal of Science Education, 20(2), 205-221.

Tsaparlis, G. (2003). Chemical phenomena versus chemical reactions: do students make the connection?. Chemistry Education Research and Practice, 4(1), 31-43.

Tsitsipis, G., Stamovlasis, D. and Papageorgiou, G. (2010). The effect of three cognitive variables on students' understanding of the particulate nature of matter and its changes of state. International Journal of Science Education, 32(8), 987-1016.

Ültay, N., Durukan, Ü. G. and Ültay, E. (2015). Evaluation of the effectiveness of conceptual change texts in the REACT strategy. Chemistry Education Research and Practice, 16(1), 22-38.

Valanides, N. (2000). Primary student teachers'understanding of the particulate nature of matter and its transformations during dissolving. Chemistry Education Research and Practice, 1(2), 249-262.

Whitelegg, E. and Parry, M. (1999). Real-life contexts for learning physics: Meanings, issues and practice. Physics Education, 34, 68-72.

Yağbasan, R. ve Gülçiçek, Ç. (2003). Fen öğretiminde kavram yanılgılarının karakteristiklerinin tanımlanması. Pamukkale Üniversitesi Eğitim Fakültesi Dergisi, $1(13), 102-120$. 